Article

\title{
Synthesis, Spectroscopic, Thermal and Catalytic Properties of Four New Metal (II) Complexes with Selected N- and O-Donor Ligands
}

\author{
Agnieszka Czylkowska *(D), Bartłomiej Rogalewicz, Anita Raducka, Natalia Błaszczyk, \\ Tomasz Maniecki, Kinga Wieczorek (D) and Paweł Mierczyński (D) \\ Institute of General and Ecological Chemistry, Faculty of Chemistry, Lodz University of Technology, \\ Zeromskiego 116, 90-924 Lodz, Poland; 211150@edu.p.lodz.pl (B.R.); anita.raducka@dokt.p.lodz.pl (A.R.); \\ natalia.blaszczyk@dokt.p.lodz.pl (N.B.); tomasz.maniecki@p.lodz.pl (T.M.); \\ kinga.wieczorek@dokt.p.lodz.pl (K.W.); pawel.mierczynski@p.lodz.pl (P.M.) \\ * Correspondence: agnieszka.czylkowska@p.lodz.pl
}

Received: 12 May 2020; Accepted: 17 July 2020; Published: 20 July 2020

\begin{abstract}
Four solid compounds with formulae: $\mathrm{Co}(\mathrm{OAc})_{2}(\mathrm{Im}) \cdot \mathrm{H}_{2} \mathrm{O}(\mathrm{I}), \mathrm{Ni}(\mathrm{OAc})_{2}(\mathrm{Im})_{1.5} \cdot 2 \mathrm{H}_{2} \mathrm{O}$ (II), $\mathrm{Cu}_{2}(\mathrm{OAc})_{4}(\mathrm{Im})(\mathrm{III})$ and $\mathrm{Zn}(\mathrm{OAc})_{2}(\mathrm{Im}) \cdot \mathrm{H}_{2} \mathrm{O}(\mathrm{IV})$ (where: $\mathrm{Im}=1 \mathrm{H}$-Imidazole) were prepared and characterized by chemical and elemental analysis, powder X-ray diffraction patterns and FTIR spectroscopy. Catalytic properties of each complex for styrene oxidation reaction were investigated. Furthermore, thermal properties of compounds were studied using the TG-DTG and DSC techniques under dry air atmosphere. Additionally, volatile thermal decomposition and fragmentation products were also investigated using the TG-FTIR spectra in air.
\end{abstract}

Keywords: metal (II) complexes; imidazole; acetates; XRD; TG-DTG; DSC; TG-FTIR; catalyst; styrene oxidation

\section{Introduction}

Complexes are chemical compounds which can be characterized by various functions induced by ligands incorporated into their structure. One of the most widely used ligands in complexes' structures is imidazole. Complexes containing an imidazole ring in their structure are widespread in natural environment and many of them display important biological functions. This N-Donor ligand itself is a well-known heterocyclic aromatic compound which is commonly used as a component of medicines. Many of its derivatives, such as alkaloids and antifungal drugs, have biological functions. Imidazoles are a group of antifungal agents that was introduced in the 1980s, which can be divided into two groups: diazoles-containing two nitrogen atoms in the five-membered azole ring [1-8]. The second ligand has carboxylate group which can create different types of binding with metal ions $[9,10]$. It often acts as bidentate ligand, through electron pairs of two oxygen atoms in its molecule [11-13]. In addition, it is used in various industries and in chemical synthesis for the production of other important chemicals. This well-known building block is widely used in cosmetics as a $\mathrm{pH}$ regulator. It is also used in food production as a preservative: it protects food against development of bacteria and fungi, thus prolonging their durability. It is also used for dyeing fabrics in the textile industry $[14,15]$. Coordination compounds of metal ions with both organic ligands are an interesting and promising field of research. In literature we can find similar compounds to those we obtained, however, with different stoichiometric ratios. They have been synthesized and structurally described [16-23]; some of them form dimeric metal complexes [24-27] or polymeric structures [28,29]. Such variety of possible interactions between metals and ligands draws attention to further investigations of these compounds, 
for this type of compounds thermal and catalytic properties have not been studied yet. The material in this paper fills an existing gap in the literature on these compounds. Here, we present synthesis and investigation of physical and chemical properties of new solid $\mathrm{Co}$ (II), $\mathrm{Ni}$ (II), $\mathrm{Cu}$ (II) and $\mathrm{Zn}$ (II) complexes with title ligands. After establishing the composition, we thoroughly investigated their thermal properties. It is an important issue, taking into consideration their possible future applications. All of them are stable at room temperature and, when heated, decompose to neutral metal oxides. One of the possible future applications of these compounds is catalysis. Their catalytic properties have been tested for styrene oxidation reaction with promising results. Besides satisfactory conversion, these compounds can also be described as stable and relatively simple structures. Oxidation reaction of aromatic compounds like styrene draws interest not only from researchers but also from industry. Oxidation reaction speed largely depends on the nature of these compounds, their molecular weight and steric configuration. Usually oxidation of styrene is carried out in the presence of peracids but this process leads to undesirable products. To overcome these limitations, an ecological oxidizer $\left(\mathrm{H}_{2} \mathrm{O}_{2}\right)$ is used. However, the most important issue is the choice of catalyst that allows for reasonable conversion of the compounds. Therefore, $\mathrm{Co}$ (II), Ni (II), Cu (II) and Zn (II) complexes have been tested as catalysts in the styrene oxidation reaction $[30,31]$.

\section{Materials and Methods}

\subsection{Materials, Synthesis and Analysis}

Imidazole, acetic acid, $\mathrm{CoCO}_{3}, \mathrm{NiCO}_{3} \cdot 2 \mathrm{Ni}(\mathrm{OH})_{2}, \mathrm{CuCO}_{3} \cdot \mathrm{Cu}(\mathrm{OH})_{2}$ and $\mathrm{ZnCO}_{3}$ from Sigma Aldrich (Poland) were used. Water solutions of metal (II) acetates were prepared by adding $2 \mathrm{~mol} \cdot \mathrm{L}^{-1}$ acetic acid to metal (II) carbonates or metal (II) carbonate hydroxides. The reactions were carried out for $24 \mathrm{~h}$ at room temperature $\left(25^{\circ} \mathrm{C}\right)$. After that time, the undissolved precipitates were filtered off. Obtained metal (II) acetates solutions were further analyzed: after appropriate dilution, contents of metal (II) ions were determined by AAS technique. Standard solutions Merck (1000 mg/L, Darmstadt, Germany) were used for preparation of calibration curves. For analysis, distilled water with electrical conductivity $0.05 \mu \mathrm{S}$ was applied (water deionizer system Polwater).

The mixed-ligand complexes were prepared by mixing $2.5 \mathrm{mmol}$ of imidazole in $96 \% \mathrm{v} / \mathrm{v}$ ethanol with freshly obtained water solutions of $2.5 \mathrm{mmol}$ metal (II) acetates. Reaction mixtures were then stirred on a magnetic stirrer for $4 \mathrm{~h}$. The synthesis was carried out at room temperature $(\mathrm{pH}=5-6)$. After a few days, compounds were crystallized. Products were filtered off and dried in air at room temperature. Synthesis is schematically presented on Figure 1 and described by reactions below.

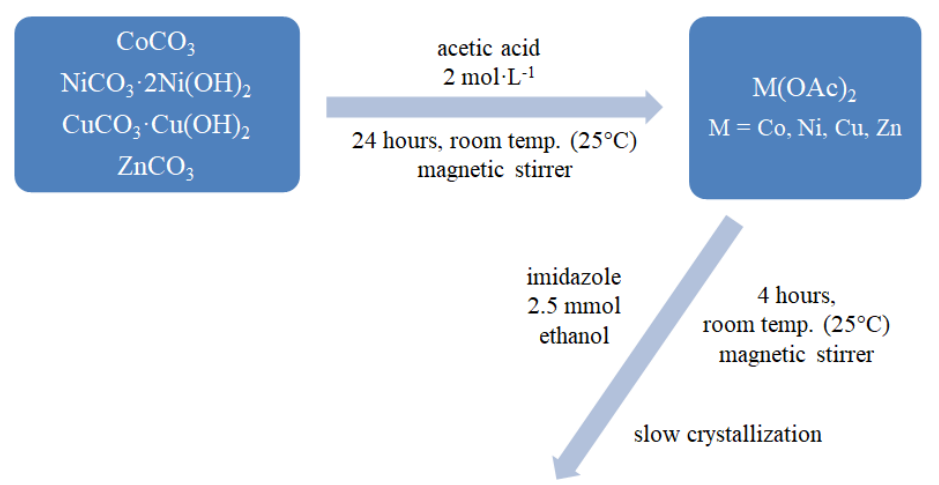

$\mathrm{Co}(\mathrm{OAc})_{2}(\mathrm{Im}) \cdot \mathrm{H}_{2} \mathrm{O}$

$\mathrm{Ni}(\mathrm{OAc})_{2}(\mathrm{Im})_{1.5} \cdot 2 \mathrm{H}_{2} \mathrm{O}$

$\mathrm{Cu}_{2}(\mathrm{OAc})_{4}(\mathrm{Im})$

$\mathrm{Zn}(\mathrm{OAc})_{2}(\mathrm{Im}) \cdot \mathrm{H}_{2} \mathrm{O}$

Figure 1. Synthesis path for mixed-ligand complexes. 


$$
\begin{gathered}
\mathrm{MCO}_{3}+2 \mathrm{HOAc} \stackrel{24 \text { h, room temp. }}{\longrightarrow} \mathrm{M}(\mathrm{OAc})_{2}+\mathrm{CO}_{2}+\mathrm{H}_{2} \mathrm{O}, \text { where } \mathrm{M}(\mathrm{II})=\mathrm{Co}, \mathrm{Zn} \\
\mathrm{CuCO}_{3} \cdot \mathrm{Cu}(\mathrm{OH})_{2}+4 \mathrm{HOAc} \stackrel{24 \text {, room temp. }}{\longrightarrow} 2 \mathrm{Cu}(\mathrm{OAc})_{2}+\mathrm{CO}_{2}+2 \mathrm{H}_{2} \mathrm{O} \\
\mathrm{NiCO}_{3} \cdot 2 \mathrm{Ni}(\mathrm{OH})_{2}+6 \mathrm{HOAc} \stackrel{24 \text {, room temp. }}{\longrightarrow} 3 \mathrm{Ni}(\mathrm{OAc})_{2}+\mathrm{CO}_{2}+3 \mathrm{H}_{2} \mathrm{O} \\
\mathrm{M}(\mathrm{OAc})_{2} \cdot \mathrm{H}_{2} \mathrm{O}+\mathrm{Im} \stackrel{4 h \text {, room temp. }}{\longrightarrow} \mathrm{M}(\mathrm{OAc})_{2}(\mathrm{Im}) \cdot \mathrm{H}_{2} \mathrm{O} \downarrow \text {, where } \mathrm{M}(\mathrm{II})=\mathrm{Co}, \mathrm{Zn} \\
2 \mathrm{Cu}(\mathrm{OAc})_{2}+\mathrm{Im} \stackrel{4 \text {, room temp. }}{\longrightarrow} \mathrm{Cu}_{2}(\mathrm{OAc})_{4}(\mathrm{Im}) \downarrow \\
\mathrm{Ni}(\mathrm{OAc})_{2} \cdot 2 \mathrm{H}_{2} \mathrm{O}+1.5 \mathrm{Im} \stackrel{4 \text {, room temp. }}{\longrightarrow} \mathrm{Ni}(\mathrm{OAc})_{2}(\mathrm{Im})_{1.5} \cdot 2 \mathrm{H}_{2} \mathrm{O} \downarrow
\end{gathered}
$$

Samples of complexes (about $20 \mathrm{mg}$ ) were digested in a mixture of concentrated $36 \% \mathrm{HCl}(1 \mathrm{~mL})$ and $65 \% \mathrm{HNO}_{3}(6 \mathrm{~mL})$ and the contents of metals were determined using the same methodology as for the metal (II) acetates solutions.

The contents of $\mathrm{C}, \mathrm{H}$ and $\mathrm{N}$ in prepared compounds were determined by a Vario micro company Elementar Analysensysteme GmbH (Langenselbold, Germany)

The catalytic activity tests were carried out in liquid phase, product analysis was done using GC-chromatograph equipped with FID detector (HP 5890) (Hewlett Packard Corporation, Palo Alto, CA, USA). The catalytic liquid-phase oxidation reactions of styrene were used to study the catalytic activity of complexes. Reactions were carried out in a $50 \mathrm{~mL}$ round-bottom flask. The molar ratio of reagents was $\mathrm{C}_{2} \mathrm{H}_{3} \mathrm{~N}: \mathrm{H}_{2} \mathrm{O}_{2}: \mathrm{C}_{8} \mathrm{H}_{8}=1: 1: 1$. The mixture was stirred in a water bath at $60{ }^{\circ} \mathrm{C}$ and refluxed. The catalyst $(0.01 \mathrm{~g})$ was added after reaching this temperature.

The analysis of styrene content was performed by gas chromatography equipped with a flame ionization detector (GD-FID, HP 5890, Hewlett Packard Corporation). The optimal parameters of method were as follows: separation column: ZB-FFAP capillary column $(30 \mathrm{~m} \times 0.25 \mathrm{~mm} \times 0.25 \mu \mathrm{m})$; oven profile: $60^{\circ} \mathrm{C}$ for $8 \mathrm{~min}$ to $150{ }^{\circ} \mathrm{C} / \mathrm{min}$ for $4 \mathrm{~min}$; injection temperature $225^{\circ} \mathrm{C}$; injection split: 11:8:1, $0.5 \mu \mathrm{L}$; detector temperature: $250^{\circ} \mathrm{C}$; carrier gas: helium $3.4 \mathrm{~mL} / \mathrm{min}$. Conversion degree was determined according to the following formula:

$$
\text { Conversion }=\left[\frac{A_{0}-A_{2}}{A_{0}}\right] \times 100 \%
$$

$\mathrm{A}_{0}$ is the initial concentration of styrene in reactant mixture; $\mathrm{A}_{2}$ is the concentration of styrene after $2 \mathrm{~h}$ in reactant mixture.

\subsection{Methods and Instruments}

The contents of $\mathrm{Co}$ (II), Ni (II), Cu (II) and Zn (II) in acetates and solid complexes were determined by the F-AAS spectrometer (Analityk Jena, contraAA 300, Jena, Germany) with a continuum source of light and using air/acetylene flame (Analityk Jena, contraAA 300). Absorbances were measured at analytical spectral lines: $240.7 \mathrm{~nm}$ for Co (II), 232.0 for Ni (II), $324.7 \mathrm{~nm}$ for Cu (II) and $213.9 \mathrm{~nm}$ for $\mathrm{Zn}$ (II). Limits of quantification were $0.04 \mathrm{mg} / \mathrm{L}$ for Co (II) and Cu (II), $0.005 \mathrm{mg} / \mathrm{L}$ for Zn (II) and $0.09 \mathrm{mg} / \mathrm{L}$ for Ni (II). Solid samples were decomposed using the Anton Paar Multiwave 3000 (Graz, Austria) closed system instrument. Mineralization was carried out for $45 \mathrm{~min}$ at $240{ }^{\circ} \mathrm{C}$ under pressure 60 bar. FTIR spectra were recorded with an IRTracer-100 Schimadzu Spectrometer $\left(3800-800 \mathrm{~cm}^{-1}\right.$ with an accuracy of recording of $1 \mathrm{~cm}^{-1}$, Kyoto, Japan) using $\mathrm{KBr}$ pellets. Thermal properties of complexes in air were studied using STA 449 F1 Jupiter Netzsch (Selb, Germany) coupled with FTIR Tensor27 Bruker (Ettlingen, Germany) in the temperature range $25-1000{ }^{\circ} \mathrm{C}$ at a heating rate of $10{ }^{\circ} \mathrm{C} \cdot \mathrm{min}^{-1}$, in flowing dynamic air atmosphere $\mathrm{v}=20 \mathrm{~mL} \cdot \mathrm{min}^{-1}$ using ceramic crucibles; as a reference material, ceramic crucibles were used. Room temperature powder X-ray diffraction patterns were collected using a PANalytical X'Pert Pro MPD diffractometer (PANalytical, Almelo, The Netherlands) in the Bragg-Brentano reflection geometry. Copper $\mathrm{CuK}_{\alpha}$ radiation from a sealed tube was used. Data were 
collected in the $2 \theta$ range $5-90^{\circ}$ with a step of $0.0167^{\circ}$ and an exposure per step of $50 \mathrm{~s}$. The samples were spun during data collection to minimize preferred orientation effects. A PANalytical X'Celerator detector based on Real Time Multiple Strip technology and capable of simultaneously measuring intensities in the $2 \theta$ range of $2.122^{\circ}$ was used.

\section{Results}

\subsection{Elemental Analysis}

As a result of the two-step synthesis, four new solid mixed-ligand complexes with the following formulas: $\mathrm{Co}(\mathrm{OAc})_{2}(\mathrm{Im}) \cdot \mathrm{H}_{2} \mathrm{O}(\mathrm{I}), \mathrm{Ni}(\mathrm{OAc})_{2}(\mathrm{Im})_{1.5} \cdot 2 \mathrm{H}_{2} \mathrm{O}(\mathrm{II}), \mathrm{Cu}_{2}(\mathrm{OAc})_{4}(\mathrm{Im})$ (III) and $\mathrm{Zn}(\mathrm{OAc})_{2}(\mathrm{Im}) \cdot \mathrm{H}_{2} \mathrm{O}(\mathrm{IV})$ were obtained. Table 1 presents results of the elemental and chemical analysis of investigated complexes. These compounds are stable in air in solid state. They do not change their stoichiometric composition.

Table 1. Analytical data for synthesized compounds.

\begin{tabular}{cccccc}
\hline \multirow{2}{*}{ No. } & \multirow{2}{*}{ Compound } & \multicolumn{4}{c}{ Analysis: (Found) Calculated/\% } \\
\cline { 3 - 6 } & & $\mathbf{M}$ & $\mathbf{C}$ & $\mathbf{H}$ & $\mathbf{N}$ \\
\hline \multirow{2}{*}{ (I) } & $\mathrm{Co}(\mathrm{OAc})_{2}(\mathrm{Im}) \cdot \mathrm{H}_{2} \mathrm{O}$ & 22.40 & 31.95 & 4.56 & 10.64 \\
& & $(22.43)$ & $(31.90)$ & $(4.59)$ & $(10.59)$ \\
(II) & $\mathrm{Ni}(\mathrm{OAc})_{2}(\mathrm{Im})_{1.5} \cdot 2 \mathrm{H}_{2} \mathrm{O}$ & 18.64 & 32.39 & 5.08 & 13.34 \\
& & $(18.59)$ & $(32.48)$ & $(5.06)$ & $(13.42)$ \\
$(\mathrm{III})$ & $\mathrm{Cu}_{2}(\mathrm{OAc})_{4}(\mathrm{Im})$ & 29.46 & 30.63 & 3.53 & 6.49 \\
& & $(28.94)$ & $(31.18)$ & $(3.50)$ & $(6.45)$ \\
$(\mathrm{IV})$ & $\mathrm{Zn}(\mathrm{OAc})_{2}(\mathrm{Im}) \cdot \mathrm{H}_{2} \mathrm{O}$ & 24.25 & 31.15 & 4.45 & 10.39 \\
& & $(24.19)$ & $(31.05)$ & $(4.43)$ & $(10.43)$ \\
\hline
\end{tabular}

\subsection{X-ray Diffraction Data}

The analysis of power diffraction patterns of these compounds revealed that they are small crystalline (Figures 2-5). Although Co (II) and Zn (II) complexes have the same composition, they are not isostructural compounds. Powder diffraction patterns of all complexes do not occur in Powder Diffraction File [32].

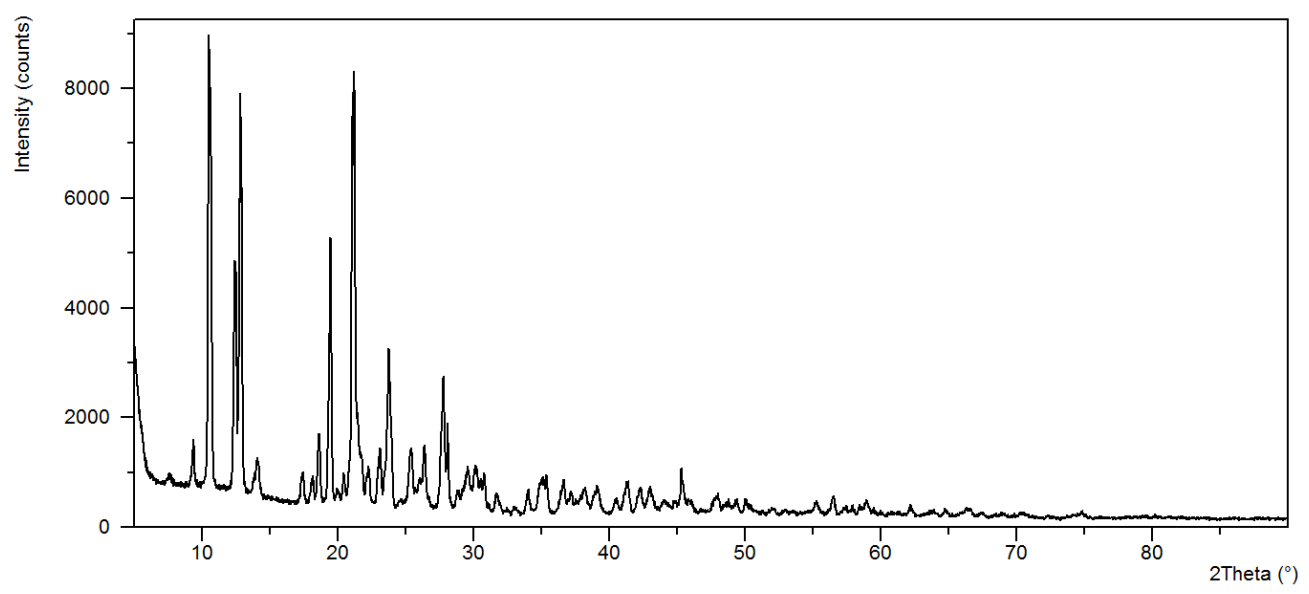

Figure 2. The diffraction pattern of $\mathrm{Co}(\mathrm{OAc})_{2}(\mathrm{Im}) \cdot \mathrm{H}_{2} \mathrm{O}$. 


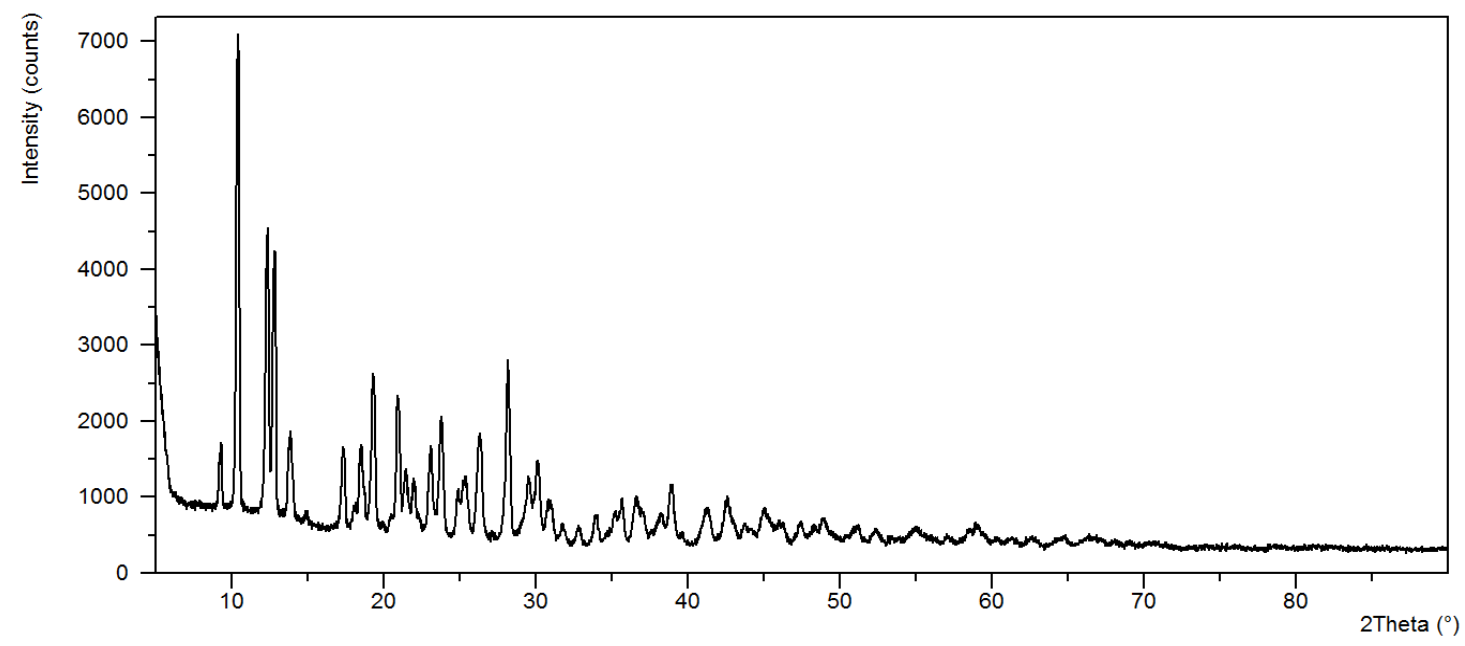

Figure 3. The diffraction pattern of $\mathrm{Ni}(\mathrm{OAc})_{2}(\mathrm{Im})_{1.5} \cdot 2 \mathrm{H}_{2} \mathrm{O}$.

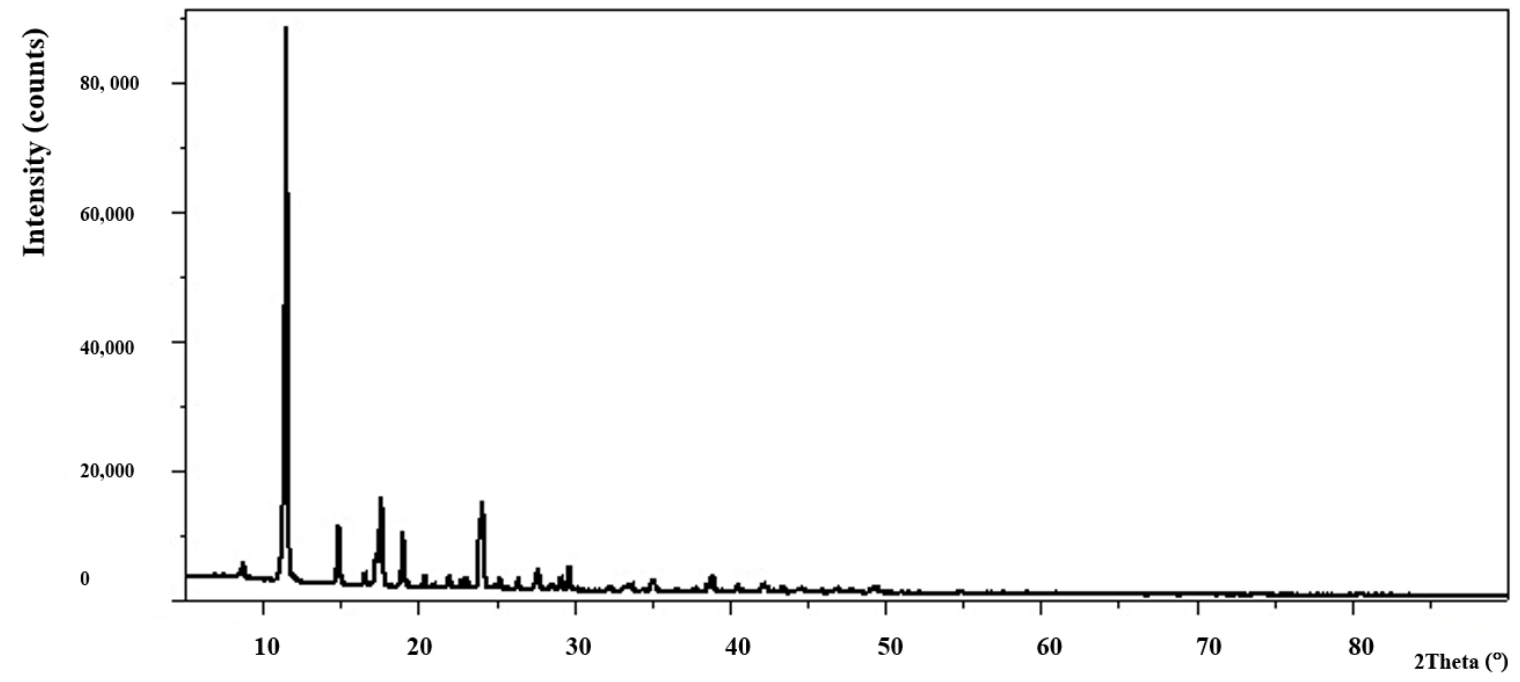

Figure 4. The diffraction pattern of $\mathrm{Cu}_{2}(\mathrm{OAc})_{4}(\mathrm{Im})$.

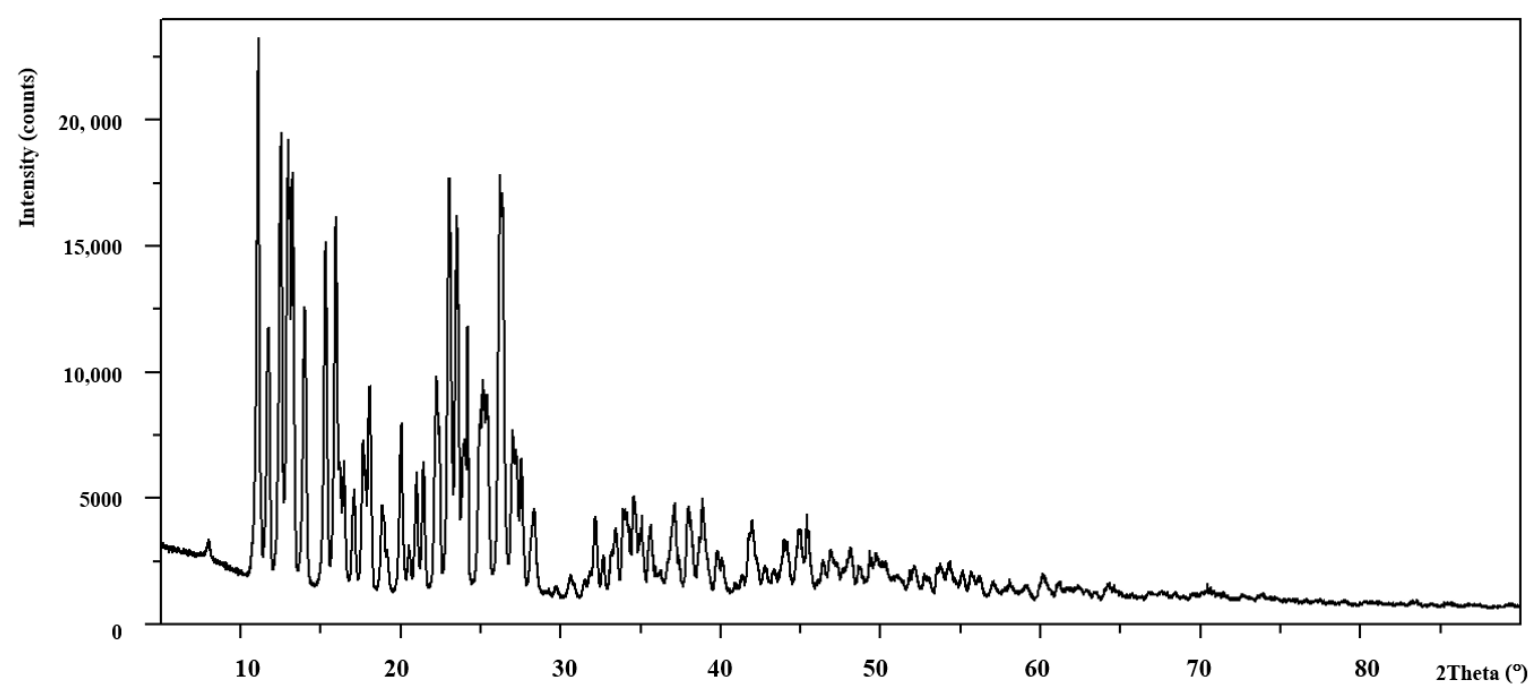

Figure 5. The diffraction pattern of $\mathrm{Zn}(\mathrm{OAc})_{2}(\mathrm{Im}) \cdot \mathrm{H}_{2} \mathrm{O}$. 


\subsection{FTIR Spectra}

The fundamental vibration modes of imidazole, -COO groups and complexes are reported in Table 2 (Figure 6). During coordination with metal (II) ions, the vibration modes of free $\mathrm{N}$ and O-donors change. The fundamental stretching vibration modes $v(\mathrm{NH})$ and $v(\mathrm{CH})$ (in free ligand at $3124 \mathrm{~cm}^{-1}$ ) occur in the range $3143-3114 \mathrm{~cm}^{-1}$ in the complexes spectra. In the free ligand spectra, a strong band of around $1645 \mathrm{~cm}^{-1}$ is assigned to the vibration mode $v(\mathrm{C}=\mathrm{N})$. For complexes this band is shifted to lower wavenumbers by $45-18 \mathrm{~cm}^{-1}$ compared to the spectra of free imidazole. In the absorption region of $\mathrm{N}$-donor ligand appear also the modes: $\delta(\mathrm{CN}), v(\mathrm{CC})$ and $v(\mathrm{CN})$. In the free ligand, they are visible at $1540 \mathrm{~cm}^{-1}$. They are moved to the higher and lower frequencies as a result of coordination between metal ion and $\mathrm{N}$-donor ligand. In the spectra of uncoordinated ligand there are also vibrations of $\delta(\mathrm{CN}), \pi(\mathrm{CH})$ and $\delta$ (imidazole ring). In complexes, they are shifted in comparison to free imidazole. Changes of vibration modes $v(\mathrm{NH}), v(\mathrm{CH}), v(\mathrm{CN}), \delta(\mathrm{CN}), v(\mathrm{CC}), \delta(\mathrm{CN}), \pi(\mathrm{CH})$ and $\delta$ (imidazole ring) of complexes in comparison to the spectra of free imidazole prove the existence of binding between imidazole and metal ions [33,34].

Table 2. Fundamental FTIR bands $\left[\mathrm{cm}^{-1}\right]$ for imidazole and -COO groups in obtained complexes.

\begin{tabular}{|c|c|c|c|c|c|c|c|c|}
\hline Compound & $v(\mathrm{NH})$ & $v(\mathrm{CH})$ & $v(\mathrm{CN})$ & $\begin{array}{l}\delta(\mathrm{NH}), \\
v(\mathrm{CC}), \\
v(\mathrm{CN})\end{array}$ & $\begin{array}{c}\delta(\mathrm{CH}) \\
\delta \text { (imidazole } \\
\text { ring) }\end{array}$ & $\begin{array}{c}\pi(\mathrm{CH}) \\
\delta \text { (imidazole } \\
\text { ring) }\end{array}$ & $v_{\text {as }}(\mathrm{COO})$ & $v_{\mathrm{s}}(\mathrm{COO})$ \\
\hline $\mathrm{NaOAc}$ & - & - & - & - & - & - & 1578 & 1414 \\
\hline imidazole & 3124 & 3014 & 1645 & 1540 & 937 & 894 & - & - \\
\hline $\mathrm{Co}(\mathrm{OAc})_{2}(\mathrm{Im}) \cdot \mathrm{H}_{2} \mathrm{O}$ & $\begin{array}{l}3139 \\
3118\end{array}$ & 3058 & 1600 & 1546 & 952 & 883 & 1571 & $\begin{array}{l}1415 \\
1409\end{array}$ \\
\hline $\mathrm{Ni}(\mathrm{OAc})_{2}(\mathrm{Im})_{1.5} \cdot 2 \mathrm{H}_{2} \mathrm{O}$ & 3120 & 3047 & 1612 & 1537 & 910 & 868 & $\bullet$ & 1415 \\
\hline $\mathrm{Cu}_{2}(\mathrm{OAc})_{4}(\mathrm{Im})$ & $\begin{array}{l}3143 \\
3118\end{array}$ & 3056 & 1627 & 1552 & 916 & 869 & 1519 & $\begin{array}{l}1409 \\
1360\end{array}$ \\
\hline $\mathrm{Zn}(\mathrm{OAc})_{2}(\mathrm{Im}) \cdot \mathrm{H}_{2} \mathrm{O}$ & $\begin{array}{l}3139 \\
3114\end{array}$ & 3058 & $\begin{array}{l}1621 \\
1610\end{array}$ & 1548 & 954 & 887 & 1577 & 1419 \\
\hline
\end{tabular}

$\bullet-$ Overlaid by N-donor ligand

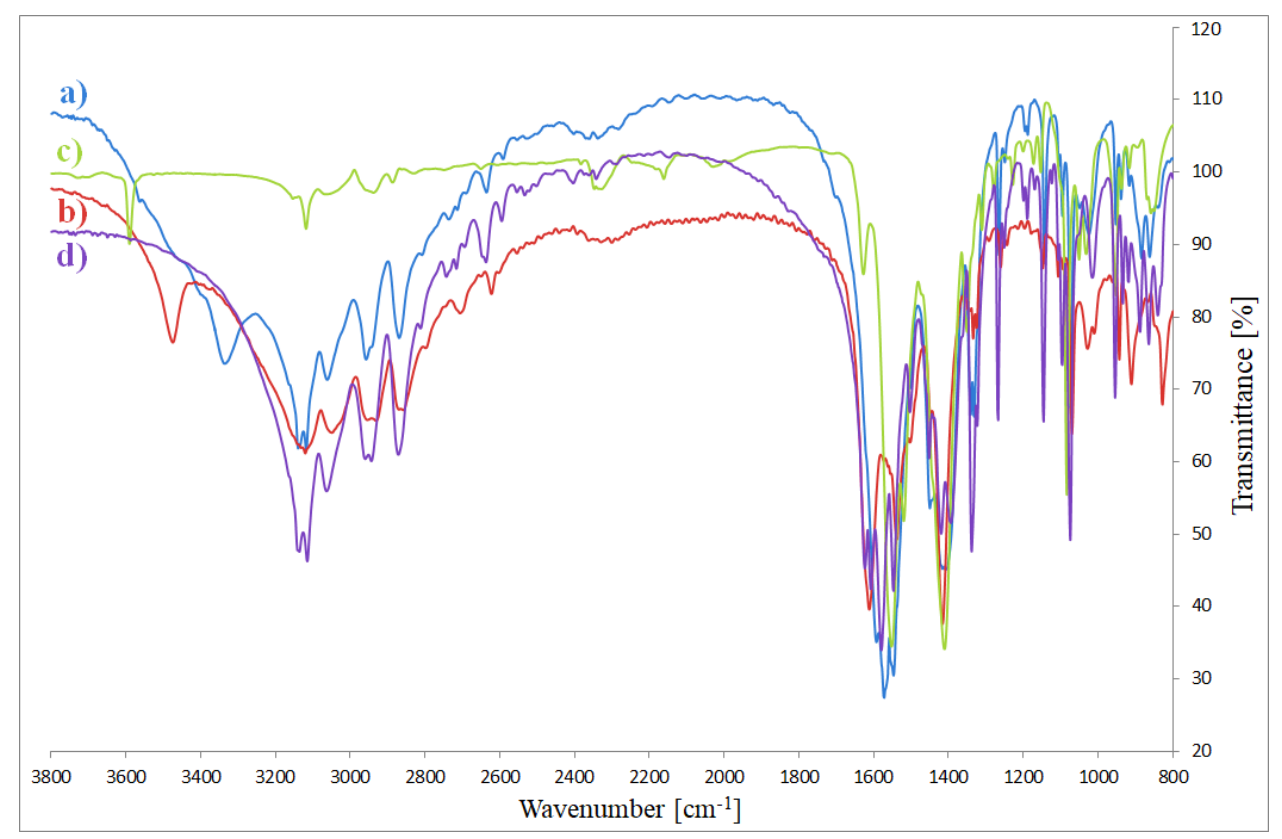

Figure 6. FTIR spectra of complexes: (a) $\mathrm{Co}(\mathrm{OAc})_{2}(\mathrm{Im}) \cdot \mathrm{H}_{2} \mathrm{O},(\mathbf{b}) \mathrm{Ni}(\mathrm{OAc})_{2}(\mathrm{Im})_{1.5} \cdot 2 \mathrm{H}_{2} \mathrm{O},(\mathbf{c}) \mathrm{Cu}_{2}(\mathrm{OAc})_{4}(\mathrm{Im})$, (d) $\mathrm{Zn}(\mathrm{OAc})_{2}(\mathrm{Im}) \cdot \mathrm{H}_{2} \mathrm{O}$. 
Acetate is the ligand which may coordinate in different ways. The way of coordination carboxylate group is described by spectroscopic criteria [35,36]. Nakamoto [35] and Alcock and co-authors [36] compared values of separation of asymmetric $\left(v_{\text {as }}(\mathrm{COO})\right)$ and symmetric $\left(v_{\mathrm{s}}(\mathrm{COO})\right)$ frequencies of complexes with these bands for sodium salt of carboxylate ligand. The separation $\Delta v=v_{\text {as }}(\mathrm{COO})-v_{\mathrm{s}}(\mathrm{COO})$ characterizes the nature of metal carboxylate bond. When $\Delta v_{\mathrm{Na}}>\Delta v_{\text {complex }}$ carboxylate group is a bidentate chelating, in case of $\Delta v_{\mathrm{Na}}<\Delta v_{\text {complex }}$ it coordinates as monodentate ligand and for $\Delta v_{\mathrm{Na}} \approx \Delta v_{\text {complex }}$ acts as bidentate-bridging donor [35,36].

In the spectra of complexes, there are also visible vibrations of asymmetric $v_{\text {as }}(\mathrm{COO})$ and symmetric $v_{\mathrm{s}}(\mathrm{COO})$ modes for -COO groups from acetate ligands (Table 2). For $\mathrm{Co}$ (II) and $\mathrm{Zn}$ (II) compounds, $\Delta v_{\text {complex }}$ are similar to sodium salt. It means that, in these complexes, -COO groups coordinate as bidentate-bridging ligands. The splitting of $v_{\mathrm{s}}(\mathrm{COO})$ bands existing in the spectra of $\mathrm{Co}$ (II) compound is probably caused by formation of non-completely equivalent bonds between metal (II) and carboxylate groups [37,38]. For the $\mathrm{Cu}$ (II) compound, $\Delta v_{\text {complex }}$ is both similar and lower than for sodium salt. It means that in this complex the carboxylate groups act as bidentate-chelating and bidentate-bridging ligands. In the case of nickel (II) complex, $v_{\text {as }}(\mathrm{COO})$ bands overlap with $v(\mathrm{CN})$ bands from N-donor ligand; therefore, it is difficult to determine its type of coordination.

\subsection{Thermogravimetric Studies in Air}

All four complexes are stable at room temperature. Their thermal decompositions have been studied in air using TG-DTG (Figures 7-10) and DSC (Figures 11-14) methods. Thermal decomposition data are exhibited in Table 3.

Thermolysis of $\mathrm{Co}(\mathrm{OAc})_{2}(\mathrm{Im}) \cdot \mathrm{H}_{2} \mathrm{O}$ begins at $80^{\circ} \mathrm{C}$. In the range of $80-125^{\circ} \mathrm{C}$, half of a water molecule is released with endothermic effect at $110{ }^{\circ} \mathrm{C}$ (mass loss: found. $4.0 \%$; calc. $3.43 \%$ ). Above $125^{\circ} \mathrm{C}$, a decomposition of another half of a water molecule and 0.5 of imidazole molecule is observed (mass loss: found. $17.0 \%$; calc. $16.35 \%$ ). They are accompanied by small endothermic peaks on the DSC curve. Between $225-410{ }^{\circ} \mathrm{C}$, there is total destruction of organic ligands (mass loss: found. $49.5 \%$; calc. $49.72 \%$ ). It is confirmed by small endothermic and large exothermic effects on DSC curve. Process stops at $410{ }^{\circ} \mathrm{C}$ with $\mathrm{Co}_{3} \mathrm{O}_{4}$ as a final solid product of decomposition.

$\mathrm{Ni}(\mathrm{OAc})_{2}(\mathrm{Im})_{1.5} \cdot 2 \mathrm{H}_{2} \mathrm{O}$ is stable to $50{ }^{\circ} \mathrm{C}$. At this temperature, one and a half of water molecules are released. Mass loss is observed on TG curve: found. 8.0\%; calc. $8.58 \%$ (endothermic effect at $105^{\circ} \mathrm{C}$ ). Next, further dehydration takes place. At $160^{\circ} \mathrm{C}$ the decomposition of $\mathrm{N}$-donor ligand starts (mass loss: found. $32.0 \%$; calc. $32.43 \%$ ), with a small endothermic peak on DSC curve. In the temperature range $375-440{ }^{\circ} \mathrm{C}$, acetates decomposition occurs and $\mathrm{NiO}$ is formed. On DSC, there is one large broad exothermic effect.

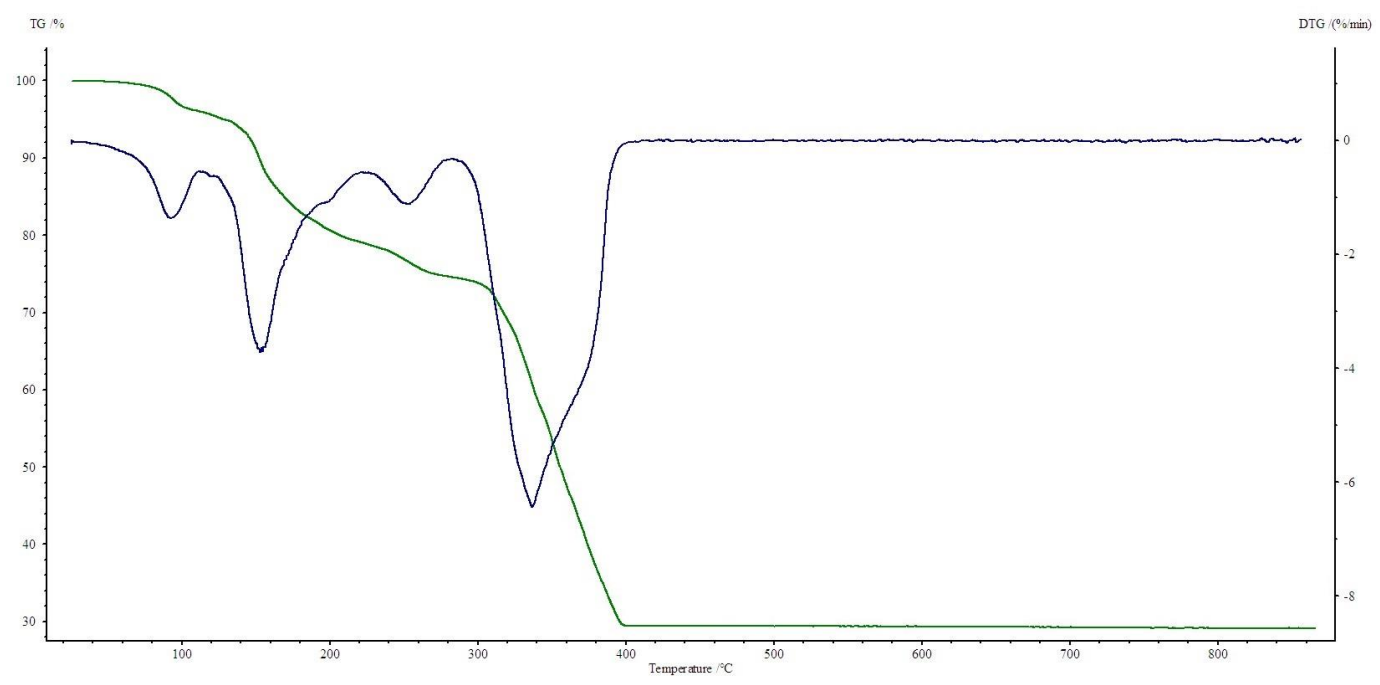

Figure 7. TG, DTG curves of $\mathrm{Co}(\mathrm{OAc})_{2}(\mathrm{Im}) \cdot \mathrm{H}_{2} \mathrm{O}$ complex in air. 


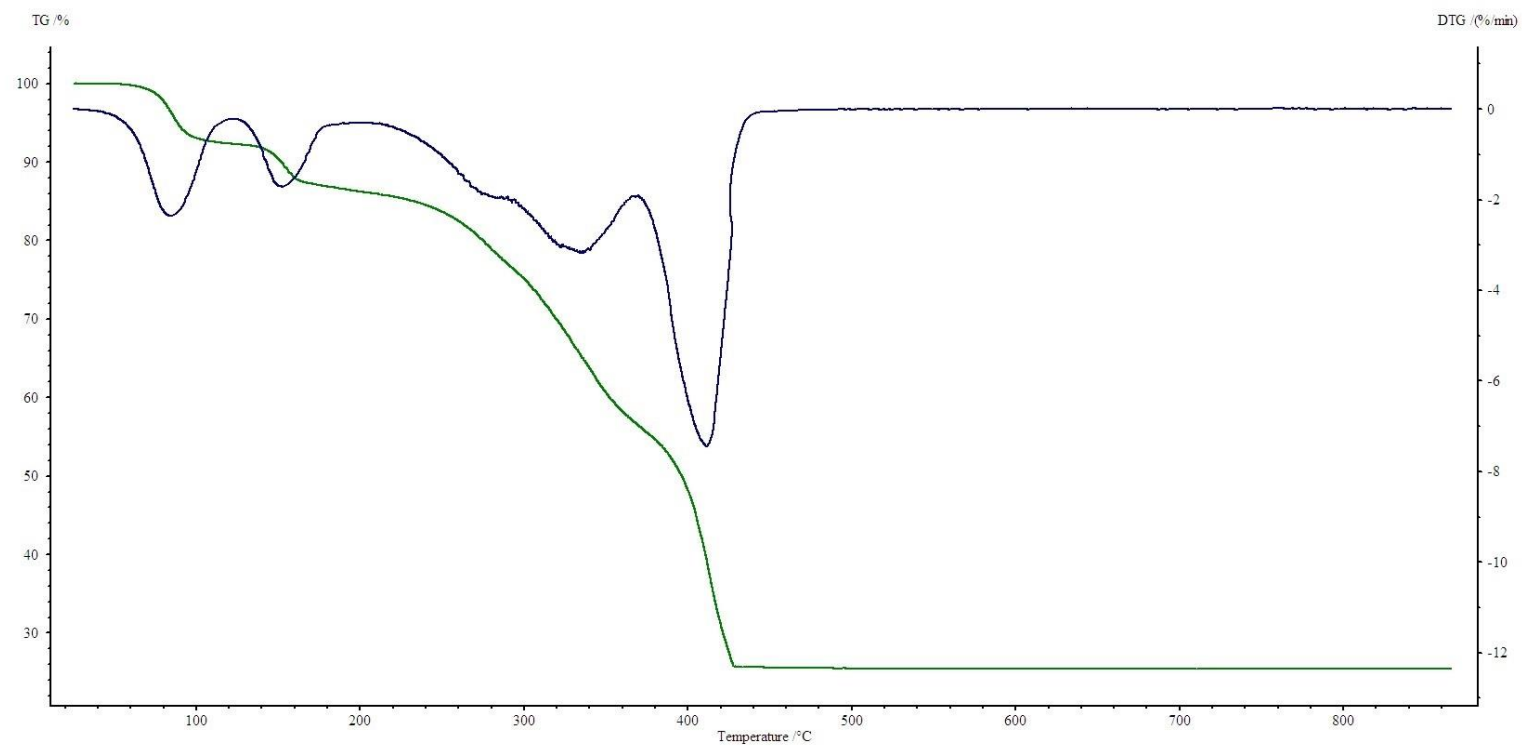

Figure 8. TG, DTG curves of $\mathrm{Ni}(\mathrm{OAc})_{2}(\mathrm{Im})_{1.5} \cdot 2 \mathrm{H}_{2} \mathrm{O}$ complex in air.

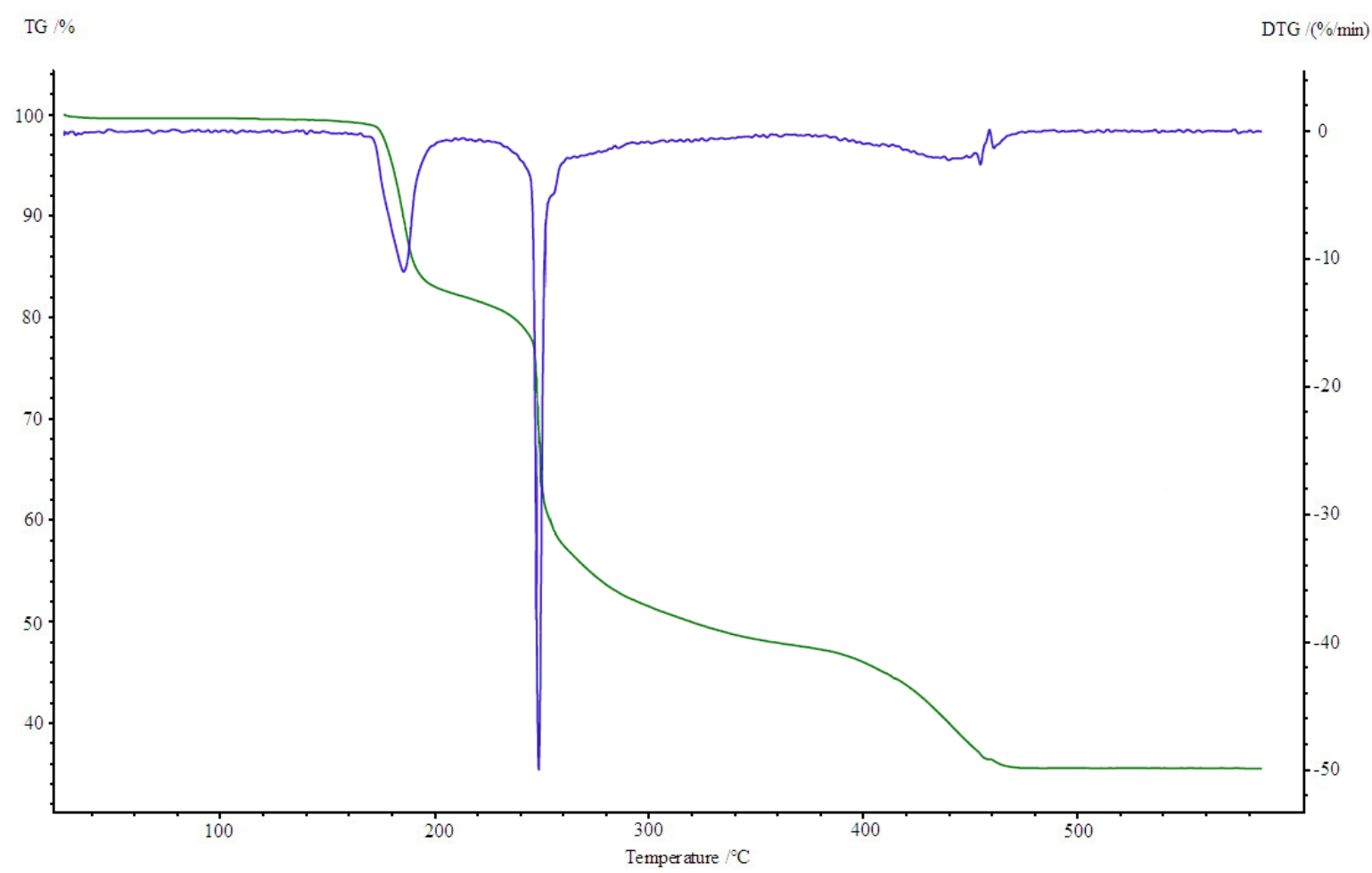

Figure 9. TG, DTG curves of $\mathrm{Cu}_{2}(\mathrm{OAc})_{4}(\mathrm{Im})$ complex in air.

Thermolysis of $\mathrm{Cu}_{2}(\mathrm{OAc})_{4}(\mathrm{Im})$ begins at $165{ }^{\circ} \mathrm{C}$. It is associated with the release of imidazole molecule (mass loss: found. 16.0\%; calc. 15.78\%). An endothermic peak appears at $190{ }^{\circ} \mathrm{C}$ on the DSC curve. When the temperature rises $\left(200-340{ }^{\circ} \mathrm{C}\right)$, partial decomposition of carboxylates takes place and an intermediate compound of the formula $\mathrm{Cu}_{2}(\mathrm{OAc})_{1.5}$ is formed (mass loss: found. $34.0 \%$; calc. $34.23 \%$ ). It is connected with two exothermic effects on DSC curve at 250 and $260{ }^{\circ} \mathrm{C}$. Next, total decomposition of organic ligands occurs. The curve shows presence of exo peak at $450{ }^{\circ} \mathrm{C}$, which is associated with combustion of the remaining carbonization products. Horizontal mass level for pure $\mathrm{CuO}$ begins at $490^{\circ} \mathrm{C}$ (found. $13.5 \%$; calc. $13.12 \%$ ). 


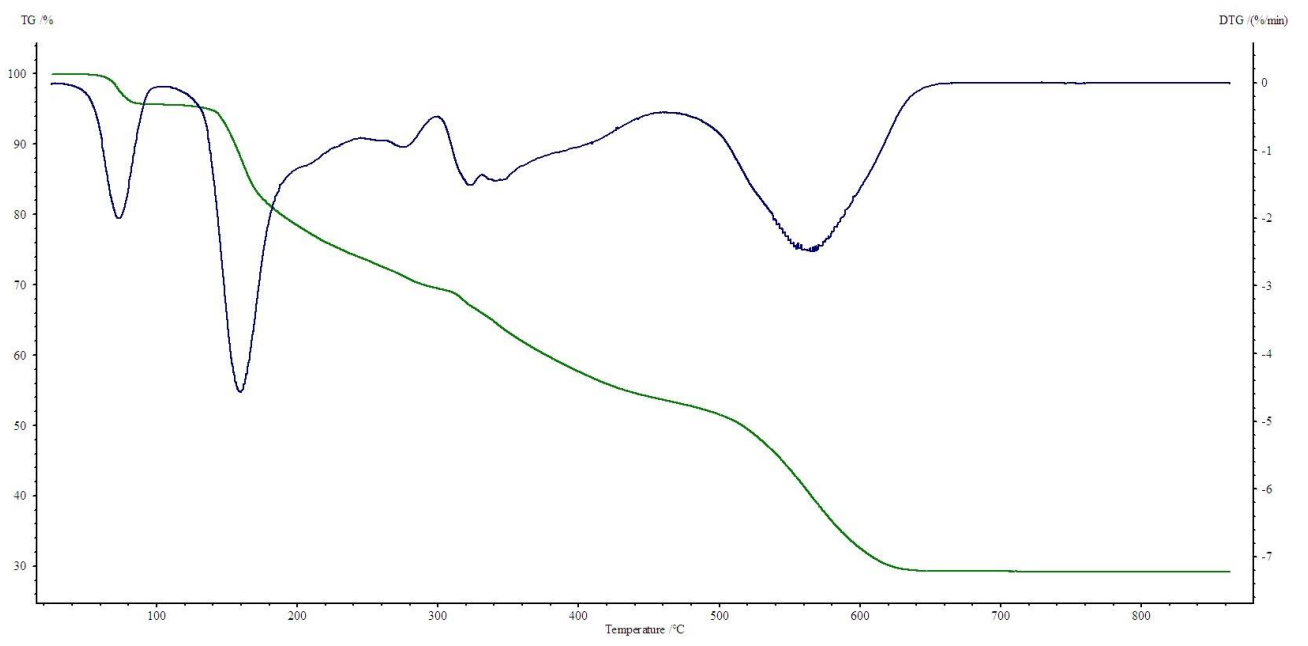

Figure 10. TG, DTG curves of $\mathrm{Zn}(\mathrm{OAc})_{2}(\mathrm{Im}) \cdot \mathrm{H}_{2} \mathrm{O}$ complex in air.

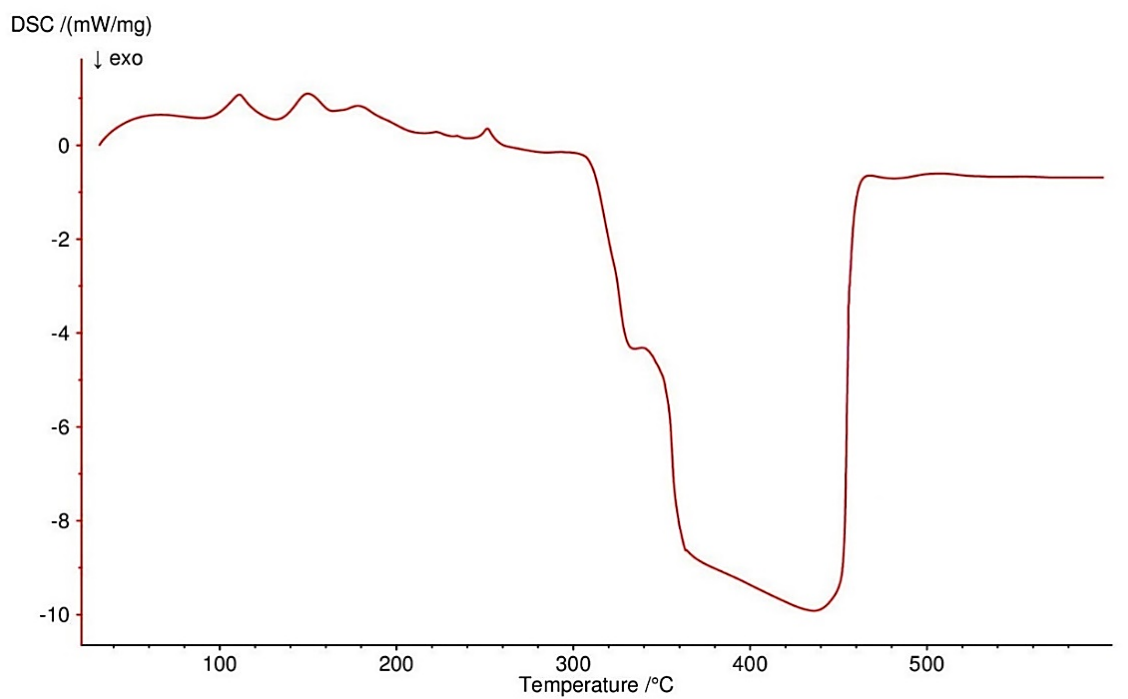

Figure 11. DSC curve of $\mathrm{Co}(\mathrm{OAc})_{2}(\mathrm{Im}) \cdot \mathrm{H}_{2} \mathrm{O}$ complex in air.

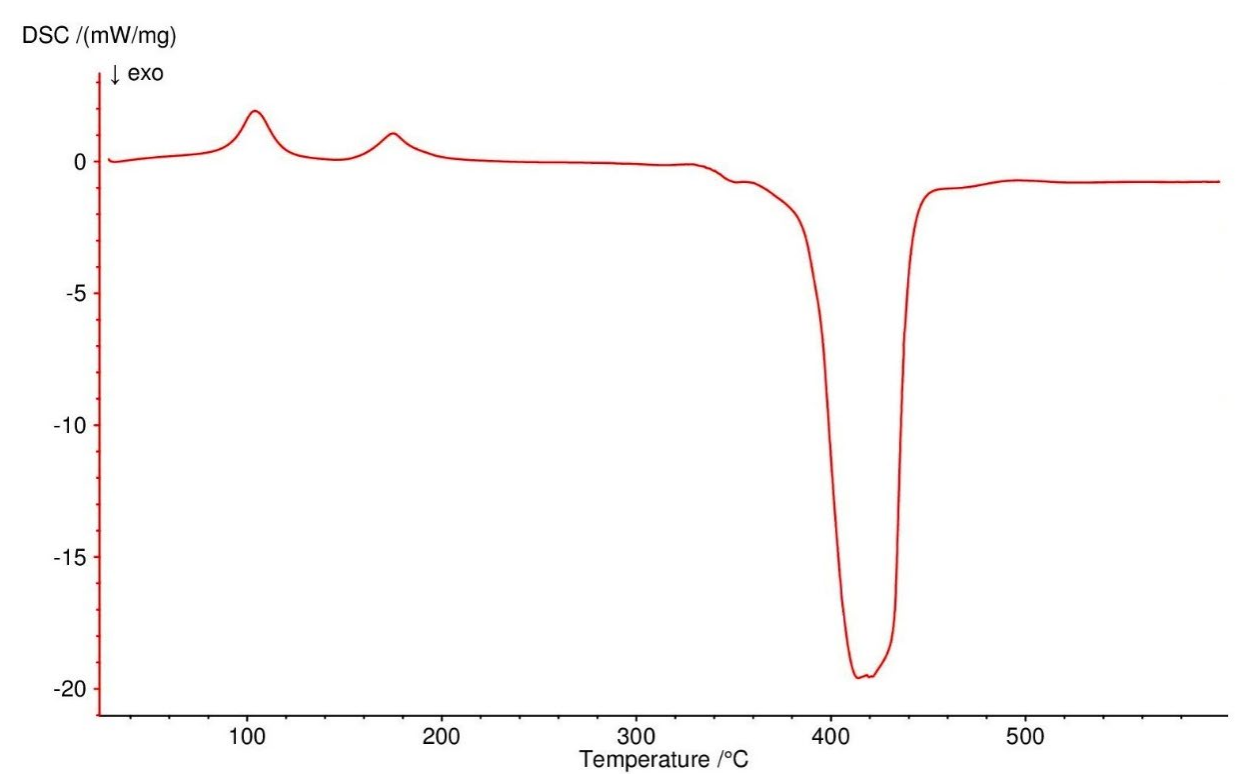

Figure 12. DSC curve of $\mathrm{Ni}(\mathrm{OAc})_{2}(\mathrm{Im})_{1.5} \cdot 2 \mathrm{H}_{2} \mathrm{O}$ complex in air. 


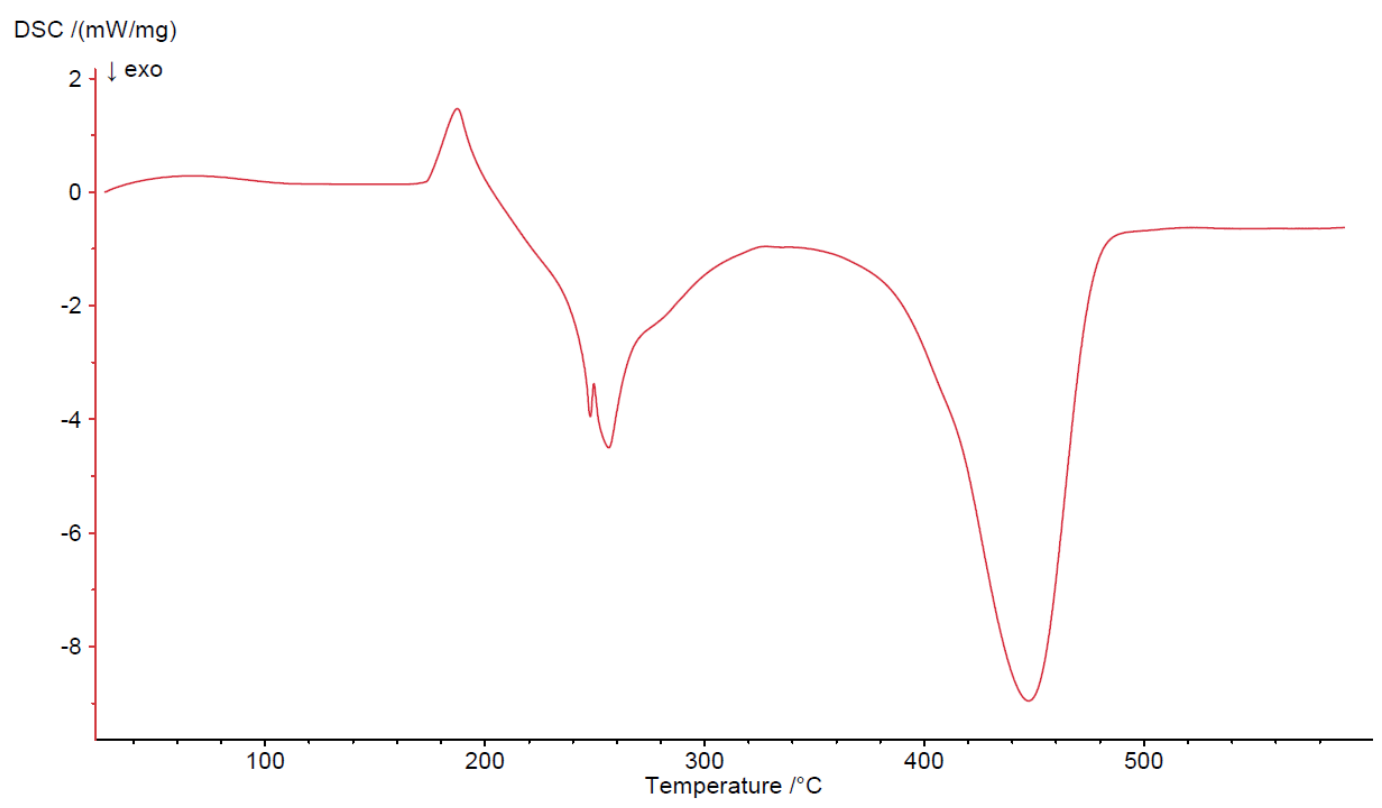

Figure 13. DSC curve of $\mathrm{Cu}_{2}(\mathrm{OAc})_{4}(\mathrm{Im})$ complex in air.

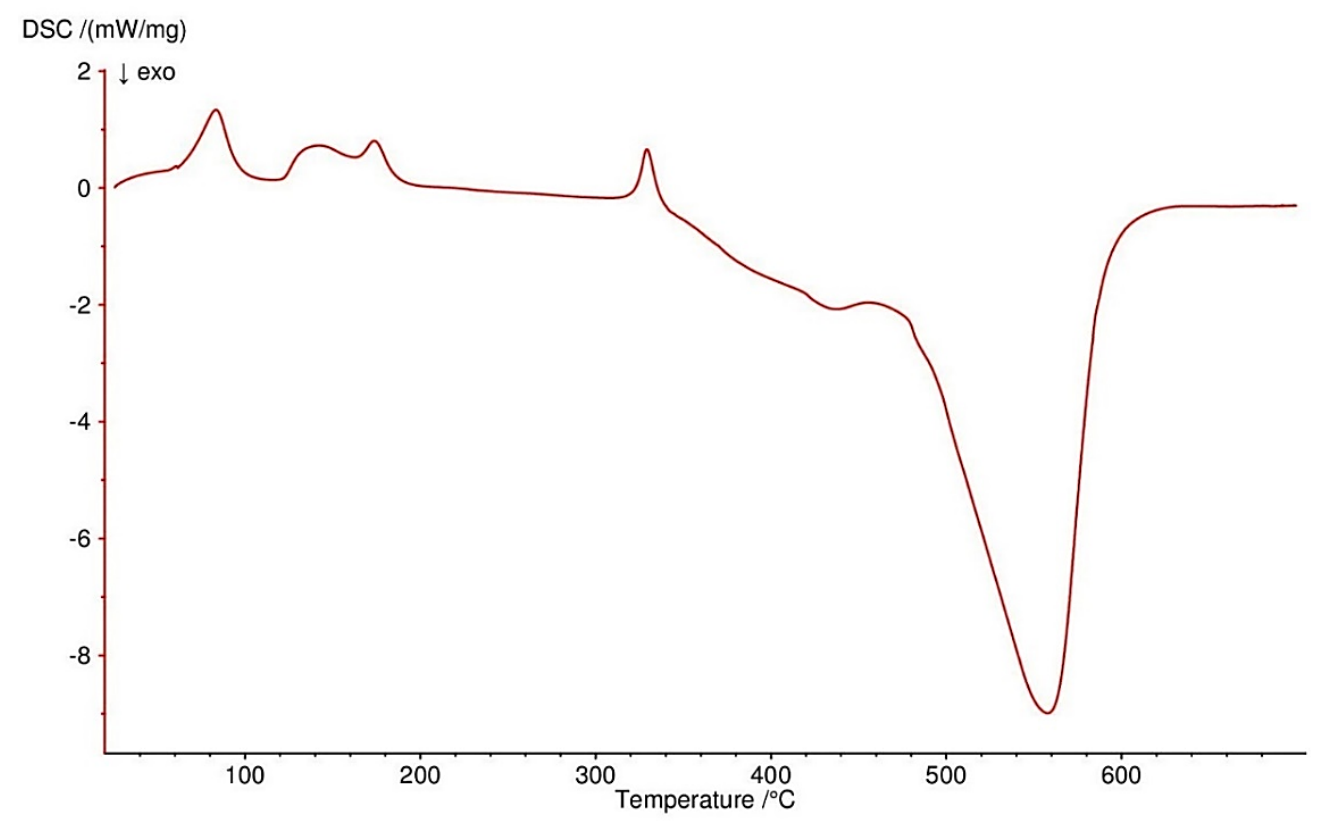

Figure 14. DSC curve of $\mathrm{Zn}(\mathrm{OAc})_{2}(\mathrm{Im}) \cdot \mathrm{H}_{2} \mathrm{O}$ complex in air.

Thermal decomposition of $\mathrm{Zn}(\mathrm{OAc})_{2}(\mathrm{Im}) \cdot \mathrm{H}_{2} \mathrm{O}$ begins at $50{ }^{\circ} \mathrm{C}$ and is connected with releasing a half of water molecule (mass loss: found. $4.0 \%$; calc. $3.34 \%$ ) with endothermic peak at $80{ }^{\circ} \mathrm{C}$. In the range of temperature $125-310^{\circ} \mathrm{C}$, further releasing of water and decomposition of an imidazole molecule occurs (mass loss: found. $28.0 \%$; calc. $28.62 \%$ ). These processes are accompanied by two endothermic effects. Above $310^{\circ} \mathrm{C}$, acetates are decomposed with endothermic and broad exothermic effects on DSC curve. The final solid product is pure $\mathrm{ZnO}$. 
Table 3. Thermal decomposition data of obtained compounds.

\begin{tabular}{|c|c|c|c|c|c|}
\hline \multirow{2}{*}{ Compound } & \multirow{2}{*}{$\begin{array}{c}\text { Range of } \\
\text { Decomposition } /{ }^{\circ} \mathrm{C}\end{array}$} & \multirow{2}{*}{ DSC Peaks $/{ }^{\circ} \mathrm{C}$} & \multicolumn{2}{|c|}{ Mass Loss/\% } & \multirow{2}{*}{$\begin{array}{c}\text { Intermediate and } \\
\text { Residue Solid } \\
\text { Products }\end{array}$} \\
\hline & & & Found & Calc. & \\
\hline \multirow{3}{*}{$\mathrm{Co}(\mathrm{OAc})_{2}(\mathrm{Im}) \cdot \mathrm{H}_{2} \mathrm{O}$} & $80-125$ & 110 endo & 4.0 & 3.43 & $\mathrm{Co}(\mathrm{OAc})_{2}(\mathrm{Im}) \cdot 0.5 \mathrm{H}_{2} \mathrm{O}$ \\
\hline & $125-225$ & 150,180 endo & 17.0 & 16.35 & $\mathrm{Co}(\mathrm{OAc})_{2}(\mathrm{Im})_{0.5}$ \\
\hline & $225-410$ & 250 endo, $330-460$ exo & 49.5 & 49.72 & $\mathrm{Co}_{3} \mathrm{O}_{4}$ \\
\hline \multirow{4}{*}{$\mathrm{Ni}(\mathrm{OAc})_{2}(\mathrm{Im})_{1.5} \cdot 2 \mathrm{H}_{2} \mathrm{O}$} & $50-125$ & 105 endo & 8.0 & 8.58 & $\mathrm{Ni}(\mathrm{OAc})_{2}(\mathrm{Im})_{1.5} \cdot 0.5 \mathrm{H}_{2} \mathrm{O}$ \\
\hline & $125-160$ & - & 3.5 & 2.86 & $\mathrm{Ni}(\mathrm{OAc})_{2}(\operatorname{Im})_{1.5}$ \\
\hline & $160-375$ & 175 endo & 32.0 & 32.43 & $\mathrm{Ni}(\mathrm{OAc})_{2}$ \\
\hline & $375-440$ & $350-440$ exo & 32.5 & 32.42 & $\mathrm{NiO}$ \\
\hline \multirow{3}{*}{$\mathrm{Cu}_{2}(\mathrm{OAc})_{4}(\mathrm{Im})$} & $165-200$ & 190 endo & 16.0 & 15.78 & $\mathrm{Cu}_{2}(\mathrm{OAc})_{4}$ \\
\hline & $200-340$ & 250,260 exo & 34.0 & 34.23 & $\mathrm{Cu}_{2}(\mathrm{OAc})_{1.5}$ \\
\hline & $340-490$ & 450 exo & 13.5 & 13.12 & $\mathrm{CuO}$ \\
\hline \multirow{3}{*}{$\mathrm{Zn}(\mathrm{OAc})_{2}(\mathrm{Im}) \cdot \mathrm{H}_{2} \mathrm{O}$} & $50-100$ & 80 endo & 4.0 & 3.34 & $\mathrm{Zn}(\mathrm{OAc})_{2}(\mathrm{Im}) \cdot 0.5 \mathrm{H}_{2} \mathrm{O}$ \\
\hline & $125-310$ & 140,170 endo & 28.0 & 28.62 & $\mathrm{Zn}(\mathrm{OAc})_{2}$ \\
\hline & $310-650$ & 330 endo, $430-600$ exo & 37.5 & 37.86 & $\mathrm{ZnO}$ \\
\hline
\end{tabular}

\subsection{TG-FTIR Studies in Air}

The coupled TG-FTIR techniques were carried out to analyze volatile thermal decomposition and fragmentation products (Figures 15-18). Based on the analysis of TG-DTG and DSC curves, we know that for the $\mathrm{Co}$ (II), Ni (II) and Zn (II) complexes, the first step of decomposition is the elimination of $0.5 \mathrm{~mol}$ of water. Dehydration begins at $50{ }^{\circ} \mathrm{C}$ for the $\mathrm{Ni}$ (II) and $\mathrm{Zn}$ (II) complexes and at $80^{\circ} \mathrm{C}$ for $\mathrm{Co}$ (II). When the temperature rises, for the $\mathrm{Co}$ (II) and $\mathrm{Ni}$ (II) compounds, total dehydration occurs and, additionally, only for Co (II) complex partial deamination take place. In the case of the $\mathrm{Zn}$ (II) complex, further loss of water goes hand in hand with total destruction of the N-donor ligand. Further heating causes a complete decomposition of organic ligands with the formation of the proper metal oxides.

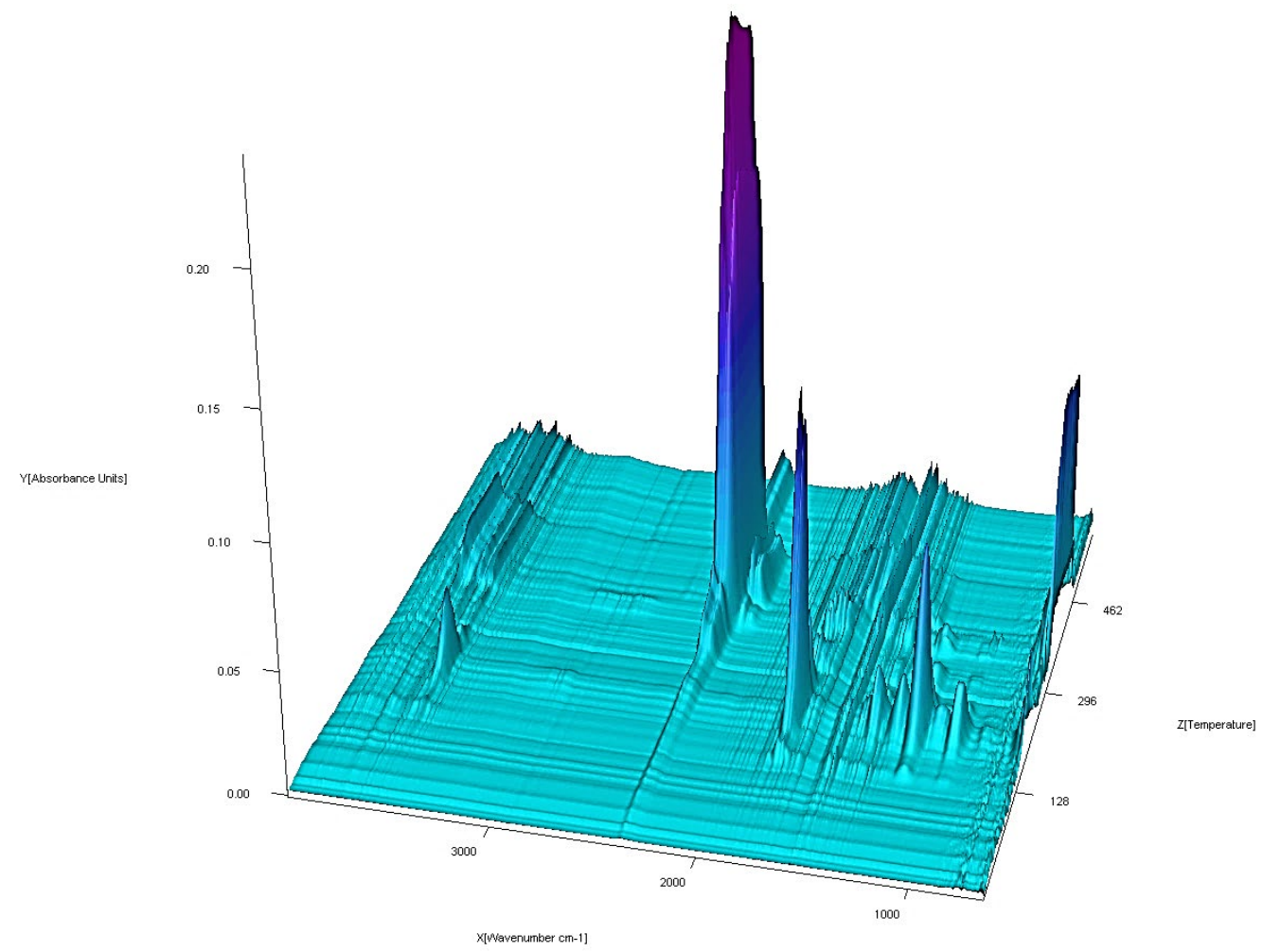

Figure 15. FTIR spectra of gaseous products produced during decomposition of $\mathrm{Co}(\mathrm{OAc})_{2}(\mathrm{Im}) \cdot \mathrm{H}_{2} \mathrm{O}$ complex in air. 


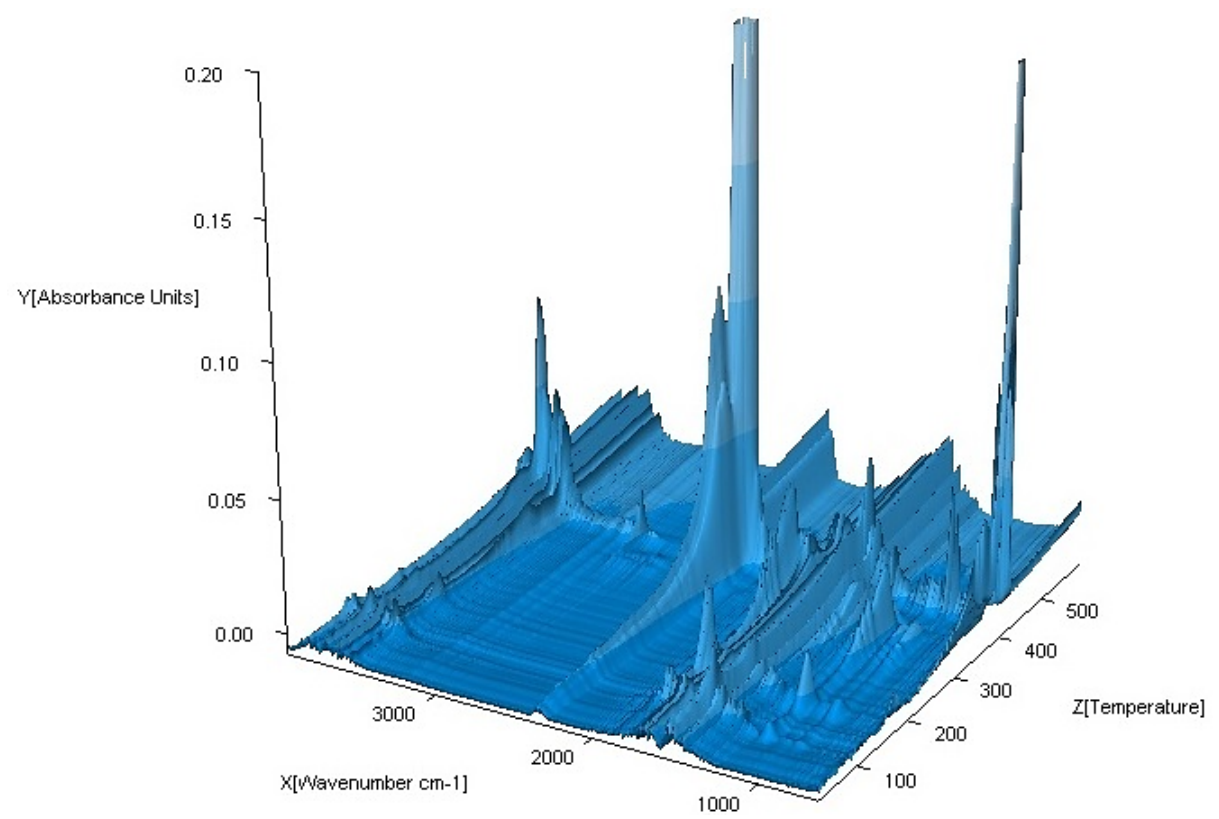

Figure 16. FTIR spectra of gaseous products produced during decomposition of $\mathrm{Ni}(\mathrm{OAc})_{2}(\mathrm{Im})_{1.5} \cdot 2 \mathrm{H}_{2} \mathrm{O}$ complex in air.

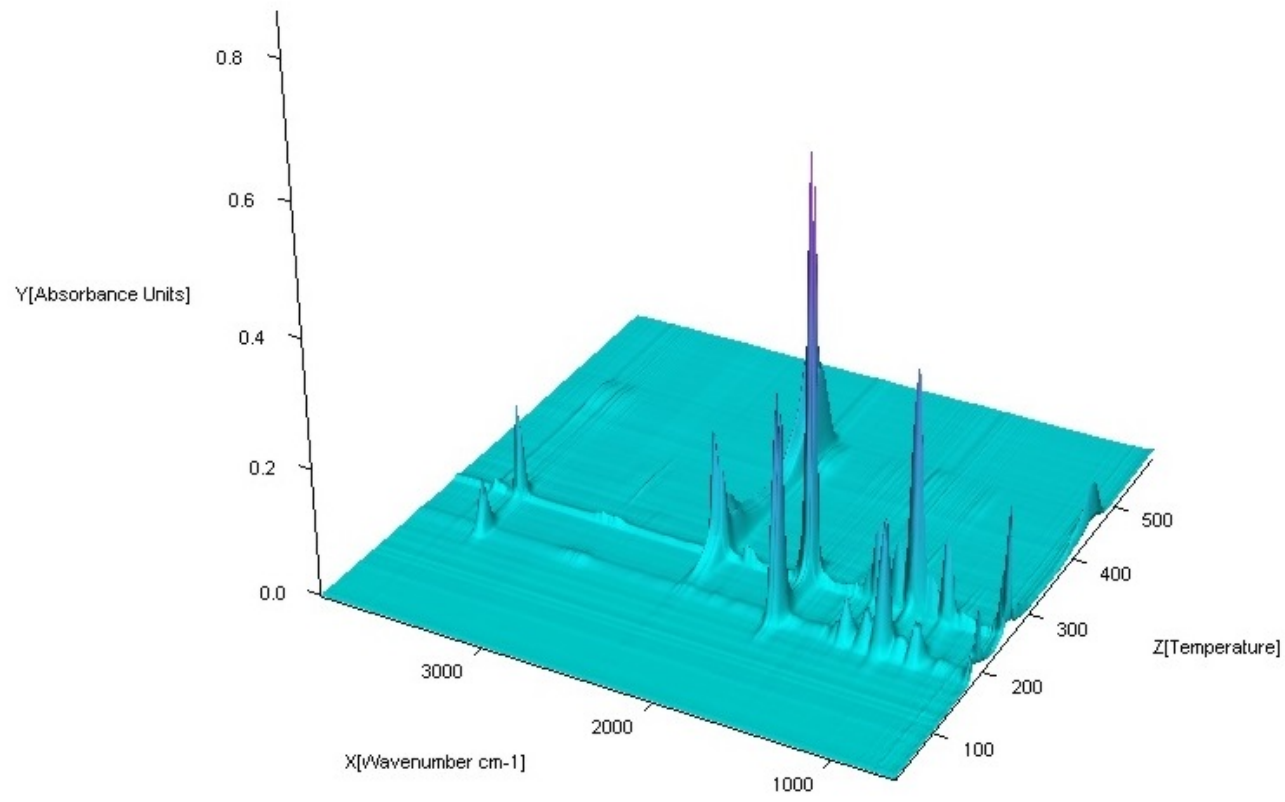

Figure 17. FTIR spectra of gaseous products produced during decomposition of $\mathrm{Cu}_{2}(\mathrm{OAc})_{4}(\mathrm{Im})$ complex in air.

The FTIR spectra of the gaseous products from the decomposition of Co (II), Ni (II) and Zn (II) compounds were similar. In low temperature of pyrolysis (about $100{ }^{\circ} \mathrm{C}$ for $\mathrm{Ni}$ (II), $\mathrm{Zn}$ (II) and $120^{\circ} \mathrm{C}$ for $\mathrm{Co}$ (II)), there are bands of stretching and deformation vibrations of liberating water. These are in the ranges of $3800-3650 \mathrm{~cm}^{-1}$ and $1850-1300 \mathrm{~cm}^{-1}$, respectively. For the $\mathrm{Cu}$ (II) complex, gaseous products start to eliminate at about $200^{\circ} \mathrm{C}$. When the temperature rises, the bands of $\mathrm{N}$-donor ligand are observed. These bands are corresponding to stretching vibrations of fragments $\mathrm{CC}$ and $\mathrm{CN}$. These occur in the range of $1800-1500 \mathrm{~cm}^{-1}$. The destruction of imidazole also causes the appearance of vibrations bands $\beta(\mathrm{CH})$ in plane in the range $1300-1200 \mathrm{~cm}^{-1}$ and $\gamma(\mathrm{CH})$ out of plane at ca. $1000 \mathrm{~cm}^{-1}$. Decomposition of organic ligands is accompanied by the formation of water and carbon dioxide. The maximum release of water and carbon dioxide are during the thermodestruction of acetate ions. It has its impact on 
the spectra: the maximum $\mathrm{CO}_{2}$ evolution was recorded at about $360^{\circ} \mathrm{C}$ for $\mathrm{Co}$ (II), $410^{\circ} \mathrm{C}$ for $\mathrm{Ni}$ (II), $420^{\circ} \mathrm{C}$ for $\mathrm{Cu}$ (II) and $560{ }^{\circ} \mathrm{C}$ for $\mathrm{Zn}$ (II) complex. The bands of the stretching and deformation molecules of $\mathrm{CO}_{2}$ are in the ranges of $2300-2250 \mathrm{~cm}^{-1}$ and $750-700 \mathrm{~cm}^{-1}$, respectively. At the same temperatures, maxima of water emission from decomposition and burning of organic ligands are observed. Further heating leads to a decrease of $\mathrm{CO}_{2}$ and $\mathrm{H}_{2} \mathrm{O}$ that proves the end of the thermal decomposition process.

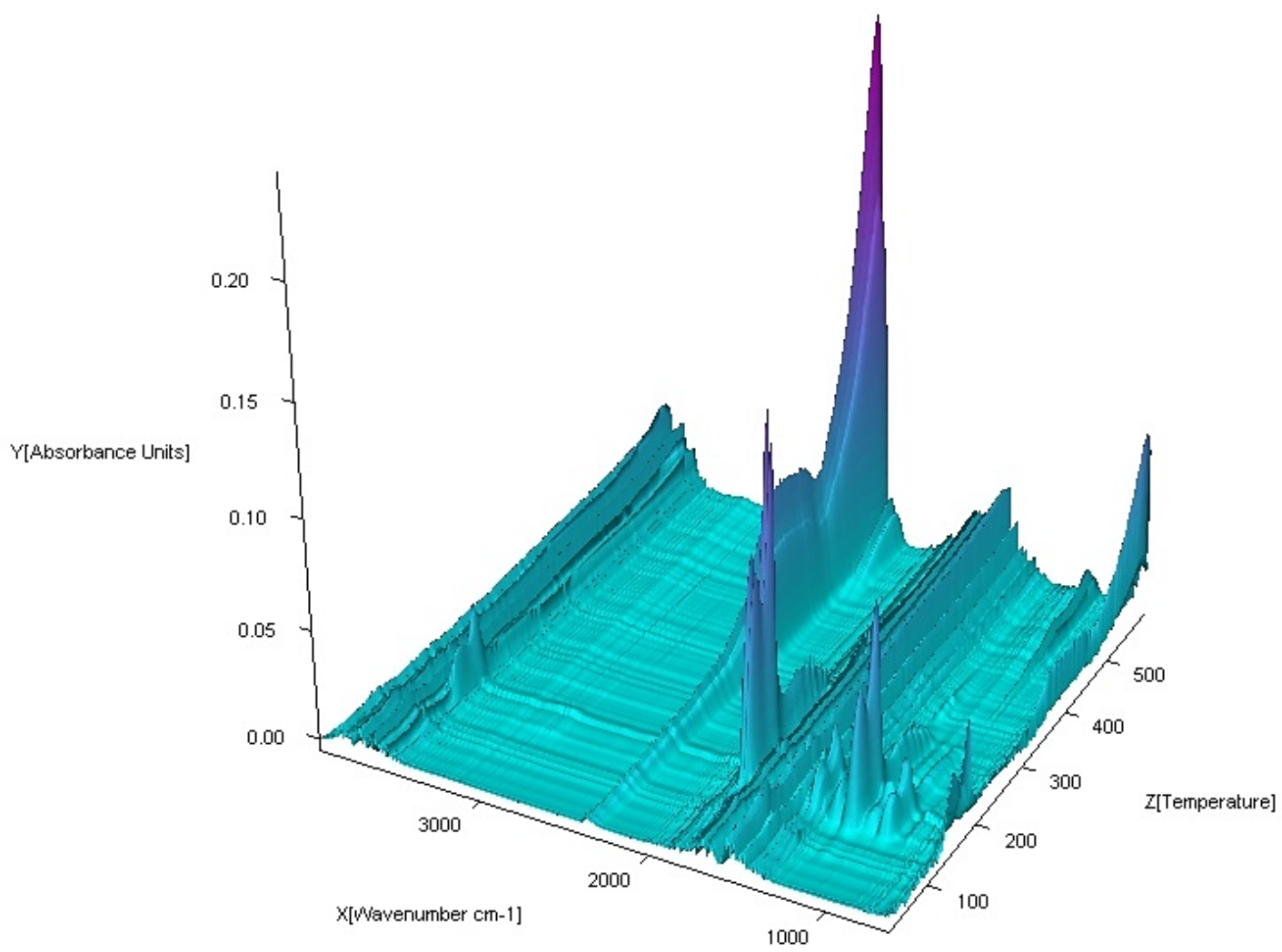

Figure 18. FTIR spectra of gaseous products produced during decomposition of $\mathrm{Zn}(\mathrm{OAc})_{2}(\mathrm{Im}) \cdot \mathrm{H}_{2} \mathrm{O}$ complex in air.

\subsection{Activity Tests in Styrene Oxidation Reaction}

All four complexes can be considered as promising highly effective catalysts for many processes which take place in liquid phase [39-41]. The catalytic efficiency was tested in styrene oxidation process in liquid phase (Figure 19). As the oxidizing agent, the hydrogen peroxide was used. The main product of that process was carbon dioxide; only small traces of benzaldehyde were detected in post reaction mixture.

Catalytic effect is related to the presence of metal complexes. It is provided by comparison of experiments conducted without a catalyst and with catalysts. The lowest conversion (up to $12 \%$ ) was observed for experiment carried out with the Ni (II) complex. For the $\mathrm{Zn}$ (II) and Cu (II) complexes, a higher conversion degree was observed: up to $19 \%$ and $21 \%$, respectively. The highest conversion after $2 \mathrm{~h}$ of reaction was observed for the Co (II) complex: up to $25 \%$. Another important determinant of utility of these compounds as catalysts is selectivity. In post reaction mixture only small traces of benzaldehyde were detected: all four complexes exhibit almost $100 \%$ selectivity towards carbon dioxide formation. The catalytic activity of metal complexes used in this experiment is associated with their structure and the type of metal atom and ligands. The difference in catalyst activity may be due to the difference in the acid-base properties of metals. 
30

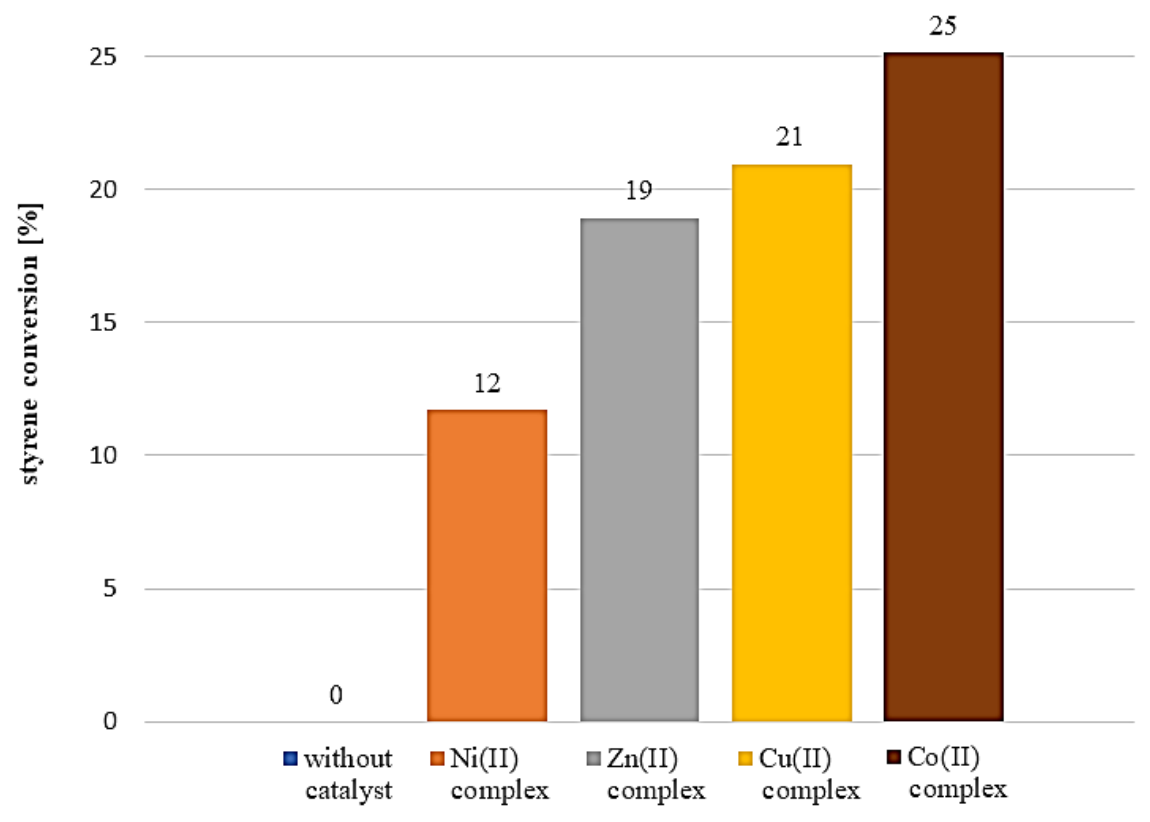

Figure 19. Percentage styrene conversion obtained with studied complexes used as catalysts.

\section{Conclusions}

Four new mixed-ligand coordination compounds with formulae: $\mathrm{Co}(\mathrm{OAc})_{2}(\mathrm{Im}) \cdot \mathrm{H}_{2} \mathrm{O}$, $\mathrm{Ni}(\mathrm{OAc})_{2}(\mathrm{Im})_{1.5} \cdot 2 \mathrm{H}_{2} \mathrm{O}, \mathrm{Cu}_{2}(\mathrm{OAc})_{4}(\mathrm{Im})$ and $\mathrm{Zn}(\mathrm{OAc})_{2}(\mathrm{Im}) \cdot \mathrm{H}_{2} \mathrm{O}$ were synthesized and isolated. Changes observed in FTIR spectra of complexes indicate that the title ligands coordinate to metal (II) ions. The thermal analysis of all the complexes confirmed that they are stable at room temperature. During heating, they decompose progressively and several processes of decomposition are weakly separated from one to another. The most stable is $\mathrm{Cu}_{2}(\mathrm{OAc})_{4}(\mathrm{Im})\left(165^{\circ} \mathrm{C}\right)$, since it does not contain any water molecule. When the temperature increases, only the $\mathrm{Ni}$ (II) complex loses total water content. In the case of $\mathrm{Co}$ (II) and $\mathrm{Zn}$ (II), this process is connected with partial and total deamination, respectively. Further heating leads to decomposition of acetates. The final solid products of pyrolysis are pure metal (II) oxides. The coupled TG-FTIR study made it possible to identify a number of gaseous species that formed and evolved during thermal decomposition of investigated complexes. The infrared spectra of volatile products recorded during heating of investigated compounds allow a better understanding of their thermal decomposition process. Emission of gaseous products in particular steps of thermal decomposition of obtained complexes corresponds with mass losses on TG curves. Performed thermal investigations are comprehensive and provide a precise view on this issue. These compounds also decompose in relatively low temperatures and final solid products of decomposition are simple inorganic oxides, which are easy to handle, store and reuse. It is especially important to take into consideration the possible use of these compounds in the future, for instance as catalysts. The catalytic activity of complexes was screened for styrene oxidation reaction. Studied complexes catalyze this reaction with satisfactory efficiency under moderate reaction conditions. All complexes exhibit almost $100 \%$ selectivity towards carbon dioxide formation. Only small traces of benzaldehyde were detected in post reaction mixture. Synthesized complex catalysts provide an efficient and safe approach to the oxidation of styrene to corresponding compounds using $\mathrm{H}_{2} \mathrm{O}_{2}$ as a mild oxidant.

Author Contributions: Conceptualization, A.C.; methodology, A.C. and T.M.; formal analysis, A.C., T.M. and B.R.; investigation, P.M., B.R., A.R., N.B. and K.W.; data curation, B.R.; writing of the original draft preparation, A.C., T.M. and B.R.; writing of review and editing, A.C., T.M. and B.R.; visualization, A.C. and B.R.; supervision, A.C.; project administration, A.C. All authors have read and agreed to the published version of the manuscript. 
Funding: This research received no external funding.

Conflicts of Interest: The authors declare no conflict of interest. The funders had no role in the design of the study; in the collection, analyses, or interpretation of data; in the writing of the manuscript, or in the decision to publish the results.

\section{References}

1. Abraham, O.C.; Manavathu, E.K.; Cutright, J.L.; Chandrasekar, P.H. In vitro susceptibilities of Aspergillus species to voriconazole, itraconazole, and amphotericin B. Diagn. Microbiol. Infect. Dis. 1999, 33, 7-11. [CrossRef]

2. Ally, R.; Schürmann, D.K.W.; Carosi, G.; Aguirrebengoa, K.; Dupont, B.; Hodges, M.; Troke, P.; Romero, A.J. A randomized, double-blind, double-dummy, multicenter trial of voriconazole and fluconazole in the treatment of esophageal candidiasis in immunocompromised patients. Clin. Infect. Dis. 2001, 33, 1447-1454. [CrossRef]

3. Andes, D.; Marchillo, K.; Stamstad, T.; Conklin, R. In Vivo Pharmacokinetics and Pharmacodynamics of a New Triazole, Voriconazole, in a Murine Candidiasis Model. Antimicrob. Agents Chemother. 2003, 47, 3165-3169. [CrossRef] [PubMed]

4. Burgess, D.S.; Hastings, R.W.; Summers, K.K.; Hardin, T.C.; Rinaldi, M.G. Pharmacodynamics of fluconazole, itraconazole, and amphotericin B against Candida albicans. Diagn. Microbiol. Infect. Dis. 2000, 36, 13-18. [CrossRef]

5. Chandrasekar, P.H.; Manavathu, E. Voriconazole: A second-generation triazole. Drugs Today 2001, 37, 135-148. [CrossRef] [PubMed]

6. Pfaller, M.A.; Sutton, D.A. Review of in vitro activity of sertaconazole nitrate in the treatment of superficial fungal infections. Diagn. Microbiol. Infect. Dis. 2006, 56, 147-152. [CrossRef]

7. Washton, H. Review of fluconazole: A new triazole antifungal agent. Diagn. Microbiol. Infect. Dis. 1989, 12, 229-233. [CrossRef]

8. Wong-Beringera, A.; Hindler, J.; Brankovic, L.; Muehlbauer, L.; Steele-Moore, L. Clinical applicability of antifungal susceptibility testing on non-Candida albicans species in hospitalized patients. Diagn. Microbiol. Infect. Dis. 2001, 39, 25-31. [CrossRef]

9. Mikuriya, M. Copper (II) acetate as a motif for metal-assembled complexes. Bull. Jpn. Soc. Coord. Chem. 2008, 52, 17-28. [CrossRef]

10. Deacon, G.B. Relationships between the carbon-oxygen stretching frequencies of carboxylato complexes and the type of carboxylate coordination. Coord. Chem. Rev. 1980, 33, 227-250. [CrossRef]

11. Czylkowska, A.; Raducka, A.; Mierczynski, P. Synthesis, thermal study and some properties of Zn(II), $\mathrm{Cd}(\mathrm{II})$ and $\mathrm{Pb}(\mathrm{II})$ compounds with mono-, di- and trichloroacetates. J. Therm. Anal. Calorim. 2017, 128, 937-946. [CrossRef]

12. Sieron, L.; Czylkowska, A.; Rogalewicz, B. Crystal structure of a one-dimensional coordination polimer of gadolinium dibromoacetate with 4,4'-bipyridine. Eur. J. Chem. 2018, 9, 178-181. [CrossRef]

13. Czylkowska, A. Synthesis, thermal study and some properties of Gd(III), Tb(III), Dy(III) and Er(III) complexes with 4,4'-bipyridine and dibromoacetates. J. Therm. Anal. Calorim. 2015, 122, 339-347. [CrossRef]

14. Fiume, M.Z. Final report on the safety assessment of triacetin. Int. J. Toxicol. 2003, 22, 1-10.

15. Kim, D.; Lim, H.-W.; Kim, S.-H.; Seo, K.H. Development of a real-time PCR assay for rapid screening of acetic acid bacteria as a group in food products. Food Control. 2019, 100, 78-82. [CrossRef]

16. Chen, X.-M.; Ye, B.-H.; Huang, X.-C.; Xu, Z.-T. Model complexes for the carboxylate-histidine-metal triad systems in metalloenzymes. Synthesis, crystal structures and spectroscopic properties of $\left[\mathrm{M}(\mathrm{Him})_{2}\left(\mathrm{O}_{2} \mathrm{CMe}\right)_{2}\right]\left(\mathrm{M}=\mathrm{Zn}^{\mathrm{II}}\right.$ or $\mathrm{Co}^{\mathrm{II}}, \mathrm{Him}=$ imidazole $) . J$. Chem. Soc. Dalton Trans. 1996, 16, 3465-3468. [CrossRef]

17. Naumov, P.; Ristova, M.; Drew, M.G.B.; Ng, S.W. Bis (acetate-O) tetrakis (imidazole- $N^{3}$ ) nickel (II). Acta Crystallogr. Sect. C Cryst. Struct. Commun. 2000, 56, e372-e373. [CrossRef]

18. Henriksson, H.A. The crystal structure of bis (imidazole) copper (II) diacetate. Acta Crystallogr. Sect. B Struct. Crystallogr. Cryst. Chem. 1977, 33, 1947-1950. [CrossRef]

19. Abuhijleh, A.; Woods, C. Synthesis, spectroscopic and structural characterization of bis (acetato) tetrakis (imidazole) copper (II): A model complex for DNA binding. Inorg. Chim. Acta 1992, 194, 9-14. [CrossRef] 
20. Horrocks, W.D., Jr.; Ishley, J.N.; Holmquist, B.; Thompson, J.S. Structural and electronic mimics of the active site of cobalt (II)-substituted zinc metalloenzymes. J. Inorg. Biochem. 1980, 12, 131-141. [CrossRef]

21. Chen, X.-M.; Xu, Z.-T.; Huang, X.-C. Dalton communications. A model complex for the carboxylatehistidine-zinc system in zinc enzymes. Crystal structure of $\left[\mathrm{Zn}(\mathrm{Him})_{2}\left(\mathrm{MeCO}_{2}\right)_{2}\right](\mathrm{Him}=$ imidazole). J. Chem. Soc. Dalton Trans. 1994, 15, 2331-2332. [CrossRef]

22. Horrocks, W.D.; Ishley, J.N.; Whittle, R.R. Models for cobalt (II)-substituted zinc metalloenzymes. 2. Comparisons of the crystal structures of complexes of the type $\left[\mathrm{M}(\mathrm{RCOO})_{2}(2-\mathrm{X}-\mathrm{Im})_{2}\right](\mathrm{Im}=$ imidazole; $\mathrm{M}=\mathrm{Co}, \mathrm{Zn} ; \mathrm{R}=\mathrm{CH}_{3}, \mathrm{C}_{2} \mathrm{H}_{5}, \mathrm{C}_{3} \mathrm{H}_{7} ; \mathrm{X}=\mathrm{CH}_{3}, \mathrm{C}_{2} \mathrm{H}_{5}$ ). An unusual type of linkage isomerism. Inorg. Chem. 1982, 21, 3270-3274. [CrossRef]

23. Gadet, A.L. Structure cristalline du complexe cobalt(lmidazole $)_{2}$ (acelate) $)_{2}$. Acta Cryst. 1974, 30, $349-353$. [CrossRef]

24. Schubert, D.M.; Visi, M.Z.; Knobler, C.B. Acid-catalyzed synthesis of zinc imidazolates and related bimetallic metal-organic framework compounds. Main Group Chem. 2008, 7, 311-322. [CrossRef]

25. Brown, D.; Glass, W.; Brown, D.; Kemp, T.; Errington, W.; Clarkson, G.; Haase, W.; Karsten, F.; Mahdy, A. Structural variations in dinuclear model hydrolases and hydroxamate inhibitor models: Synthetic, spectroscopic and structural studies. Inorg. Chim. Acta 2004, 357, 1411-1436. [CrossRef]

26. Ye, B.H.; Williams, I.D.; Li, X.Y. Syntheses and characterization of aqua-bridged dimetallic complexes, $\mathrm{M}_{2}\left(\mu-\mathrm{H}_{2} \mathrm{O}\right)(\mu-\mathrm{OAc})_{2}(\mathrm{Im})_{4}(\mathrm{OAc})_{2}\left(\mathrm{M}=\mathrm{Mg}^{2+}, \mathrm{Mn}^{2+}\right.$ and $\left.\mathrm{Ni}^{2+}\right)$. Structural models for the active sites of dimetallic hydrolases. J. Inorg. Biochem. 2002, 92, 128-136. [CrossRef]

27. Bao-Hui, Y.; Xiao-Ming, C. Syntheses, Characterization and Equilibrium between Mono-and Aqua-bridged Dicobalt (II) Complexes. A Structural Model for Methionine Aminopeptidase. Chin. J. Chem. 2010, 21, 531-536. [CrossRef]

28. Masciocchi, N.; Ardizzoia, G.A.; LaMonica, G.; Maspero, A.; Galli, S.; Sironi, A. Metal imidazolato complexes: Synthesis, characterization, and X-ray powder diffraction studies of group 10 coordination polymers. Inorg. Chem. 2001, 40, 6983-6989. [CrossRef]

29. Stamatatos, T.C.; Perlepes, S.P.; Raptopoulou, C.P.; Terzis, A.; Patrickios, C.S.; Tasiopoulos, A.J.; Boudalis, A.K. Alcoholysis/hydrolysis of 1,1'-carbonyldiimidazole as a means of preparing unprecedented, imidazole-containing one-dimensional coordination polymers of copper (II). Dalton Trans. 2009, 17, 3354-3362. [CrossRef]

30. Adam, F.; Iqbal, A. The oxidation of styrene by chromium-silica heterogeneous catalyst prepared from rice husk. Chem. Eng. J. 2010, 160, 742-750. [CrossRef]

31. Ratnasamy, P.; Kumar, R. Selective oxidation with redox metallosilicates in the production of fine chemicals. Adv. Pharmacol. 1995, 97, 367-376. [CrossRef]

32. Powder Diffraction File, PDF-2; The International Centre for Diffraction Data (ICDD): 12 Campus Boulevard, Newton Square, PA, USA, 2004.

33. Morzyk-Ociepa, B.; Różycka-Sokołowska, E.; Michalska, D. Revised crystal and molecular structure, FT-IR spectra and DFT studies of chlorotetrakis (imidazole) copper (II) chloride. J. Mol. Struct. 2012, 1028, 49-56. [CrossRef]

34. Vlaicu, I.D.; Olar, R.; Scaeteanu, G.V.; Silvestro, L.; Maurer, M.; Stanica, N.; Badea, M. Thermal, spectral and biological investigation of new nickel complexes with imidazole derivatives. J. Therm. Anal. Calorim. 2018, 134, 503-512. [CrossRef]

35. Nakamoto, K. Infrared and Raman Spectra of Inorganic and Coordination Compounds; Wiley and Sons: New York, NY, USA, 2009.

36. Alcock, N.W.; Tracy, V.M.; Waddington, T.C. Acetates and acetato-complexes. Part 2. Spectroscopic studies. J. Chem. Soc. Dalton Trans. 1976, 21, 2243-2246. [CrossRef]

37. Brzyska, W.; Ożga, W. Spectral, magnetic and thermal investigations of some d-electron element 3-methoxy-4-methylbenzoates. J. Therm. Anal. Calorim. 2006, 84, 385-389. [CrossRef]

38. Zeleňák, V.; Vargová, Z.; Györyová, K. Correlation of infrared spectra of zinc (II) carboxylates with their structures. Spectrochim. Acta Part A Mol. Biomol. Spectrosc. 2006, 66, 262-272. [CrossRef] [PubMed]

39. Gao, D.; Gao, Q. Selective oxidation of styrene to benzaldehyde over VSB-5 and isomorphously substituted cobalt VSB-5. Catal. Commun. 2007, 8, 681-685. [CrossRef] 
40. Titinchi, S.J.; Von Willingh, G.; Abbo, H.S.; Prasad, R. Tri- and tetradentate copper complexes: A comparative study on homogeneous and heterogeneous catalysis over oxidation reactions. Catal. Sci. Technol. 2015, 5, 325-338. [CrossRef]

41. Aberkouks, A.; Mekkaoui, A.A.; Boualy, B.; El Houssame, S.; Ali, M.A.; El Firdoussi, L. Selective oxidation of styrene to benzaldehyde by $\mathrm{Co}-\mathrm{Ag}$ codoped $\mathrm{ZnO}$ catalyst and $\mathrm{H}_{2} \mathrm{O}_{2}$ as oxidant. Adv. Mater. Sci. Eng. 2018, 1-7. [CrossRef]

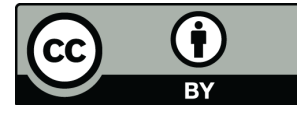

(C) 2020 by the authors. Licensee MDPI, Basel, Switzerland. This article is an open access article distributed under the terms and conditions of the Creative Commons Attribution (CC BY) license (http://creativecommons.org/licenses/by/4.0/). 